\title{
Rapid One-Pot Synthesis and Photoelectrochemical Properties of Copper Vanadates
}

\author{
Mohammad K. Hossain, ${ }^{\dagger}$ Paola Sotelo, ${ }^{\dagger}$ Hori P. Sarker, ${ }^{\ddagger}$ Miguel T. Galante, ${ }^{\S}$ Attila Kormányos, ${ }^{\|, \perp}$ \\ Claudia Longo ${ }^{\S}$ Robin T. Macaluso, ${ }^{\dagger}$ Mohammad N. Huda, ${ }^{\ddagger}$ Co Csaba Janáky, ${ }^{\|, \perp}$ \\ and Krishnan Rajeshwar* ${ }^{*}$ (i) \\ ${ }^{\dagger}$ Department of Chemistry and Biochemistry and ${ }^{\ddagger}$ Department of Physics, The University of Texas at Arlington, Arlington, Texas \\ 76019, United States \\ ${ }^{\S}$ Institute of Chemistry, University of Campinas-UNICAMP, 13083-970, Campinas, Brazil \\ "Department of Physical Chemistry and Materials Science, University of Szeged, Rerrich Square 1, Szeged, H-6720, Hungary \\ ${ }^{\perp}$ MTA-SZTE, Lendület Photoelectrochemistry Research Group, Rerrich Square 1, Szeged, H-6720, Hungary
}

\section{Supporting Information}

ABSTRACT: Solution combustion synthesis (SCS) is shown to be versatile for the rapid-one-pot synthesis of three compounds and four polymorphs in the $\mathrm{Cu}-\mathrm{V}-\mathrm{O}$ ternary family: $\alpha-\mathrm{CuV}_{2} \mathrm{O}_{6}, \alpha$ - and $\beta-\mathrm{Cu}_{2} \mathrm{~V}_{2} \mathrm{O}_{7}$, and $\gamma-\mathrm{Cu}_{3} \mathrm{~V}_{2} \mathrm{O}_{8}$. These compounds feature copper/vanadium stoichiometric ratios ranging from 1:1 to $3: 1$; their structural, electronic, optoelectronic, and photoelectrochemical attributes were comprehensively characterized by a combination of theoretical and experimental techniques. The main contribution of the present study is the demonstration that a range of stoichiometries in this compound family can be derived simply by tuning the precursor mole ratio in the SCS procedure. The $\mathrm{Cu}-\mathrm{V}-\mathrm{O}$ family of samples, derived by SCS, is shown to exemplify the strong effect of compound stoichiometry on the optoelectronic and photoelectrochemical properties. Overall, $\alpha-\mathrm{CuV}_{2} \mathrm{O}_{6}$ showed the best performance, rooted in the direct nature of the optical transition in this material. Finally, SCS is very timeefficient and the various compositions can be obtained in a matter of minutes, as opposed to hours or even days in classical solution-based or ceramic synthesis routes.

KEYWORDS: solar fuels, inorganic semiconductors, optical excitation, solar energy conversion, energy band gap, electronic band structures

\section{INTRODUCTION}

We show in this paper that solution combustion synthesis $(\mathrm{SCS})^{1-5}$ is versatile for preparing various compound stoichiometries within the $\mathrm{Cu}-\mathrm{V}-\mathrm{O}$ ternary family simply by varying the copper/vanadium mole ratio in a "one-pot" precursor mixture. Trends in the materials chemistry properties and photoelectrochemical (PEC) activity ${ }^{6,7}$ are presented as are corresponding trends in polymorphic modifications and electronic band structures. The stoichiometries of the various compounds in this family may be visualized ${ }^{8}$ in terms of the $\mathrm{CuO} / \mathrm{V}_{2} \mathrm{O}_{5}$ combining ratio in the ultimate ternary composition, as shown in the second column in Table 1 .

The combination of a narrow energy bandgap (in the $\sim 2 \mathrm{eV}$ range) and excellent stability against photocorrosion has thrust copper vanadates into the forefront of emerging photoanode materials for solar fuels generation. ${ }^{10-12,14,16,25-29}$ In the continuing search for a magic bullet semiconductor material, it is imperative that the synthesis technique is time-efficient. Otherwise, materials screening is bound to be inefficient and cost-ineffective from a practical standpoint. In this vein, this study seeks to demonstrate the virtues of SCS as a screening tool to generate a series of compounds with progressively tuned stoichiometries from a single "pot".

Interest in the structural aspects of $\mathrm{Cu}-\mathrm{V}-\mathrm{O}$ materials appears to have begun in $1958 ;^{30}$ this early study identified stoichiometries ranging from 1:1 to $5: 1$ within the system. Notably, the 4:1 stoichiometry was missing from a subsequently reported phase diagram ${ }^{31}$ and, accordingly, previous authors were unable to prepare $\mathrm{Cu}_{4} \mathrm{~V}_{2} \mathrm{O}_{9}$ (see ref 32 and references therein.) Other than the PEC applications of immediate interest within the present study context, copper vanadates are also of technological interest as lithiumintercalating battery cathodes ${ }^{9,13,15,23,33,34}$ (or even anodes ${ }^{35}$ ), thermal batteries, ${ }^{9,36}$ unique magnetic materials, ${ }^{16,17,20,37-39}$ flame retardants, ${ }^{40}$ photocatalysts for environmental remediation, ${ }^{21,23}$ or as catalysts in solar thermochemical water splitting cycles. $^{41-43}$

Received: January 24, 2019

Accepted: March 8, 2019

Published: March 8, 2019 
Table 1. Synthetic Methods for Copper Vanadates

\begin{tabular}{|c|c|c|c|c|c|}
\hline oxide composition & $\mathrm{CuO} / \mathrm{V}_{2} \mathrm{O}_{5}$ & polymorph & mineral name (crystal structure) & synthesis method & refs. \\
\hline \multirow{6}{*}{$\mathrm{CuV}_{2} \mathrm{O}_{6}$} & \multirow[t]{6}{*}{$1: 1$} & \multirow{6}{*}{$\alpha-\mathrm{CuV}_{2} \mathrm{O}_{6}$} & \multirow[t]{6}{*}{$-($ triclinic $)$} & ceramic method & 9 \\
\hline & & & & drop-casting & 10 \\
\hline & & & & inkjet printing & 11 \\
\hline & & & & sol-gel & 12,13 \\
\hline & & & & electrospray & 14 \\
\hline & & & & hydrothermal & 15 \\
\hline \multirow[t]{10}{*}{$\mathrm{Cu}_{2} \mathrm{~V}_{2} \mathrm{O}_{7}$} & \multirow[t]{10}{*}{$2: 1$} & \multirow[t]{3}{*}{$\alpha-\mathrm{Cu}_{2} \mathrm{~V}_{2} \mathrm{O}_{7}$} & \multirow[t]{3}{*}{ blossite (orthorhombic) } & ceramic method & 9 \\
\hline & & & & magnetron co-sputtering & 16 \\
\hline & & & & inkjet-printing & 11 \\
\hline & & \multirow[t]{6}{*}{$\beta-\mathrm{Cu}_{2} \mathrm{~V}_{2} \mathrm{O}_{7}$} & \multirow[t]{6}{*}{ ziesite (monoclinic) } & ceramic method & 9 \\
\hline & & & & flux growth method & 17 \\
\hline & & & & drop-casting & 10 \\
\hline & & & & magnetron co-sputtering & 16 \\
\hline & & & & inkjet printing & 11 \\
\hline & & & & electrospray & 14 \\
\hline & & $\gamma-\mathrm{Cu}_{2} \mathrm{~V}_{2} \mathrm{O}_{7}$ & $-($ triclinic $)$ & ceramic method & 18,19 \\
\hline \multirow[t]{4}{*}{$\mathrm{Cu}_{3} \mathrm{~V}_{2} \mathrm{O}_{8}$} & \multirow[t]{4}{*}{$3: 1$} & \multirow[t]{2}{*}{$\beta-\mathrm{Cu}_{3} \mathrm{~V}_{2} \mathrm{O}_{8}$} & \multirow[t]{2}{*}{ pseudolynsite (monoclinic) } & ceramic method & 20 \\
\hline & & & & solution precipitation & $21-24$ \\
\hline & & \multirow[t]{2}{*}{$\gamma-\mathrm{Cu}_{3} \mathrm{~V}_{2} \mathrm{O}_{8}$} & \multirow[t]{2}{*}{ mcbirneyite (triclinic) } & ceramic method & 20 \\
\hline & & & & magnetron cosputtering & 16,25 \\
\hline \multirow[t]{2}{*}{$\mathrm{Cu}_{11} \mathrm{~V}_{6} \mathrm{O}_{26}$} & \multirow[t]{2}{*}{$11: 3$} & \multirow[t]{2}{*}{-} & \multirow[t]{2}{*}{ fingerite (triclinic) } & electrochemical approach & 26 \\
\hline & & & & magnetron cosputtering & 16 \\
\hline \multirow[t]{2}{*}{$\mathrm{Cu}_{5} \mathrm{~V}_{2} \mathrm{O}_{10}$} & \multirow[t]{2}{*}{$5: 1$} & - & \multirow[t]{2}{*}{ stoiberite (monoclinic) } & ceramic method & 9 \\
\hline & & & & inkjet-printing & 11 \\
\hline \multicolumn{2}{|c|}{$\mathrm{CuV}_{2} \mathrm{O}_{6}, \mathrm{Cu}_{2} \mathrm{~V}_{2} \mathrm{O}_{7}, \mathrm{Cu}_{3} \mathrm{~V}_{2} \mathrm{O}_{8}$} & & & tion combustion synthesis & this study \\
\hline
\end{tabular}

Polymorphic transformations have been of interest right from the early history of study of the $\mathrm{Cu}-\mathrm{V}-\mathrm{O}$ family to the present. ${ }^{18,19,32,44-48}$ Thus, $\mathrm{Cu}_{2} \mathrm{~V}_{2} \mathrm{O}_{7}$ features three polymorphs, $\alpha$-, $\beta$-, and $\gamma$ - whose thermal interconversions have been studied ${ }^{18}$ by the combined use of X-ray diffraction (XRD) and thermal analysis (specifically, differential thermal analysis or DTA). Similar studies have been performed on phase transitions in $\mathrm{Cu}_{3} \mathrm{~V}_{2} \mathrm{O}_{8}$, where again three modifications were reported. ${ }^{44}$ Single crystals of $\alpha-\mathrm{CuV}_{2} \mathrm{O}_{6}$ and the $\beta$ - and $\gamma$ $\mathrm{Cu}_{2} \mathrm{~V}_{2} \mathrm{O}_{7}$ phases have been grown by the flux growth method or in melts. ${ }^{17,38} \mathrm{~A}$ variety of polymorphs was also seen in studies employing high throughput combinatorial methodology ${ }^{11,16}$ on $\mathrm{CuV}_{2} \mathrm{O}_{6}(\alpha-), \mathrm{Cu}_{2} \mathrm{~V}_{2} \mathrm{O}_{7}(\alpha$ - and $\beta)$, and $\mathrm{Cu}_{3} \mathrm{~V}_{2} \mathrm{O}_{8}$ $(\gamma-)$. We were able to delineate the various polymorphs in our SCS samples using XRD (with Rietveld refinement) as a function of their thermal anneal history. The photoactivity of these polymorphs will be shown to depend crucially on the stoichiometry of the copper vanadates.

Finally, experimental results on the four SCS-derived copper vanadates in this study $\left(\alpha-\mathrm{CuV}_{2} \mathrm{O}_{6}, \alpha\right.$ - and $\beta-\mathrm{Cu}_{2} \mathrm{~V}_{2} \mathrm{O}_{7}$, and $\gamma$ $\mathrm{Cu}_{3} \mathrm{~V}_{2} \mathrm{O}_{8}$ ) were corroborated by electronic band structure calculations. Precedent theoretical studies, involving density functional theory (DFT) or relativistic and $\mathrm{ab}$ initio calculations, are noted here for $\mathrm{Cu}_{2} \mathrm{~V}_{2} \mathrm{O}_{7}, \mathrm{Cu}_{3} \mathrm{~V}_{2} \mathrm{O}_{8}$, and $\mathrm{Cu}_{11} \mathrm{~V}_{6} \mathrm{O}_{26} \cdot{ }^{16,27,39,47}$ In the $\mathrm{Cu}_{2} \mathrm{~V}_{2} \mathrm{O}_{7}$ case, the electronic, structural, and magnetic properties of all three phases $(\alpha-, \beta$-, and $\gamma$-) were mapped in the first-principles study. ${ }^{16}$ The electronic structures have been experimentally mapped via the use of X-ray absorption spectroscopy. ${ }^{25}$ The overlapping aspects of our new results with the corpus of literature information summarized in this introductory section, and also presented in Table 1, will be further elaborated in what follows below.

\section{EXPERIMENTAL SECTION}

Materials. Copper nitrate hemi-(pentahydrate) $\left[\mathrm{Cu}\left(\mathrm{NO}_{3}\right)_{2} \cdot 2.5\right.$ $\mathrm{H}_{2} \mathrm{O}$ (Alfa Aesar)] and ammonium vanadate $\left[\mathrm{NH}_{4} \mathrm{VO}_{3}\right.$ (Alfa Aesar)] were used as $\mathrm{Cu}$ and $\mathrm{V}$ source, respectively. DL-malic acid $\left[\mathrm{C}_{6} \mathrm{H}_{4} \mathrm{O}_{5}\right.$ (Alfa Aesar)] was used as fuel as well as complexing agent for vanadate ion in the solutions. Sodium tetraborate decahydrate $\left[\left(\mathrm{Na}_{2} \mathrm{~B}_{4} \mathrm{O}_{7} \cdot 10 \mathrm{H}_{2} \mathrm{O}\right.\right.$ (Sigma-Aldrich) $]$ and boric acid $\left(\mathrm{H}_{3} \mathrm{BO}_{3}\right)$ were used to prepare electrolyte solutions for PEC characterizations. Double-distilled water (Corning Megapure) was used to prepare all the solutions. All the chemicals were used as received without further purification.

Solution Combustion Synthesis. Stoichiometric amounts of precursors were calculated and are shown in eqs $1-3$.

$$
\begin{aligned}
& 3 \mathrm{Cu}\left(\mathrm{NO}_{3}\right)_{2} \cdot 2.5 \mathrm{H}_{2} \mathrm{O}+6 \mathrm{NH}_{4} \mathrm{VO}_{3}+\mathrm{C}_{4} \mathrm{H}_{6} \mathrm{O}_{5} \\
& \quad \rightarrow 3 \mathrm{CuV}_{2} \mathrm{O}_{6}(\mathrm{~s})+6 \mathrm{~N}_{2}(\mathrm{~g})+4 \mathrm{CO}_{2}(\mathrm{~g})+22.5 \mathrm{H}_{2} \mathrm{O}(\mathrm{g}) \\
& 12 \mathrm{Cu}\left(\mathrm{NO}_{3}\right)_{2} \cdot 2.5 \mathrm{H}_{2} \mathrm{O}+12 \mathrm{NH}_{4} \mathrm{VO}_{3}+7 \mathrm{C}_{4} \mathrm{H}_{6} \mathrm{O}_{5} \\
& \quad \rightarrow 6 \mathrm{Cu}_{2} \mathrm{~V}_{2} \mathrm{O}_{7}(\mathrm{~s})+18 \mathrm{~N}_{2}(\mathrm{~g})+28 \mathrm{CO}_{2}(\mathrm{~g})+75 \mathrm{H}_{2} \mathrm{O}(\mathrm{g}) \\
& 3 \mathrm{Cu}\left(\mathrm{NO}_{3}\right)_{2} \cdot 2.5 \mathrm{H}_{2} \mathrm{O}+2 \mathrm{NH}_{4} \mathrm{VO}_{3}+2 \mathrm{C}_{4} \mathrm{H}_{6} \mathrm{O}_{5} \\
& \quad \rightarrow \mathrm{Cu}_{3} \mathrm{~V}_{2} \mathrm{O}_{8}(\mathrm{~s})+4 \mathrm{~N}_{2}(\mathrm{~g})+8 \mathrm{CO}_{2}(\mathrm{~g})+17.5 \mathrm{H}_{2} \mathrm{O}(\mathrm{g})
\end{aligned}
$$

A stoichiometric amount of copper nitrate was dissolved in water while stoichiometric proportions of ammonium vanadate and DL-malic acid (1:1 mol ratio) were dissolved in water. Then, the two solutions were mixed together with continuous stirring leading to the homogeneous precursor solution with a final concentration listed in Table 2. The precursor mixtures were then transferred to a preheated muffle furnace set at a temperature of $\sim 300{ }^{\circ} \mathrm{C}$ (Figure 1). The precursor mixture was first dehydrated and brought to ignition; finally sintering of the sample set in. It took 5-10 min to complete the reaction; the product at this stage is termed "as-synthesized" in what follows. The as-synthesized samples were then annealed at different temperatures, both to remove remaining organic traces and to secure improved crystallinity. 
Table 2. Concentration of precursor mixtures for different copper vanadates

\begin{tabular}{cccc} 
& \multicolumn{3}{c}{ concentration in precursor mixtures } \\
\cline { 2 - 4 } $\begin{array}{c}\text { targeted ternary oxide } \\
\text { composition }\end{array}$ & {$\left[\mathrm{Cu}\left(\mathrm{NO}_{3}\right)_{2} \cdot 2.5 \mathrm{H}_{2} \mathrm{O}\right]$} & {$\left[\mathrm{NH}_{4} \mathrm{VO}_{3}\right]$} & {$\left[\mathrm{C}_{6} \mathrm{H}_{4} \mathrm{O}_{5}\right]$} \\
$\mathrm{CuV}_{2} \mathrm{O}_{6}$ & $0.25 \mathrm{M}$ & $0.50 \mathrm{M}$ & $0.75 \mathrm{M}$ \\
$\mathrm{Cu}_{2} \mathrm{~V}_{2} \mathrm{O}_{7}$ & $0.50 \mathrm{M}$ & $0.50 \mathrm{M}$ & $1.0 \mathrm{M}$ \\
$\mathrm{Cu}_{3} \mathrm{~V}_{2} \mathrm{O}_{8}$ & $0.75 \mathrm{M}$ & $0.50 \mathrm{M}$ & $1.25 \mathrm{M}$ \\
\hline
\end{tabular}

Physical Characterizations. To study the combustion pattern of the precursor mixture, a simulation of combustion reactions was performed using thermogravimetric analysis (TGA) and differential scanning calorimetry (DSC) in a TA Instruments-Q600 instrument using an alumina crucible. Approximately $20 \mathrm{mg}$ of precursor mixture was loaded in the crucible and heated from room temperature to 800 ${ }^{\circ} \mathrm{C}$ with $5{ }^{\circ} \mathrm{C} / \mathrm{min}$ ramp under a constant air flow of $100 \mathrm{~mL} / \mathrm{min}$. Powder XRD data were collected at room temperature on a PANalytical Empyrean powder diffractometer equipped with $\mathrm{Cu} \mathrm{K} \alpha$ radiation, a Bragg-Brentano $\mathrm{HD}$ optical module and a positionsensitive PIXcel $3 \mathrm{D}$ detector. The angular range covered was $2 \theta=$ $10-70^{\circ}$ and a step size of $\Delta 2 \theta=0.008^{\circ}$ was used. Rietveld refinement of XRD patterns was carried out using X'Pert Highscore Plus ${ }^{49}$ software package employing a pseudo-Voigt function.

Scanning electron microscopy (SEM) images and energy-dispersive X-ray spectroscopy (EDX) were performed on a Hitachi-S3000 instrument. Optical analyses of the bulk powder samples were performed on a PerkinElmer Lambda 35 UV-vis spectrophotometer equipped with an integrating sphere over the range of $400-1000 \mathrm{~nm}$. The Kubelka-Munk transformation (eq 4) was applied to transform diffuse reflectance $(R)$ to absorption coefficient, $\alpha^{50}$

$$
F(R)=\frac{\alpha}{s}=\frac{\left(1-R_{\infty}\right)^{2}}{2 R_{\infty}}
$$

Energy bandgaps were estimated using the Tauc plot based on eq $5^{50}$

$$
h \nu=\alpha\left(h \nu-E_{\mathrm{g}}\right)^{n}
$$

Here, $E_{\mathrm{g}}$ denotes the bandgap and $n$ represents the mode of transition, i.e., $n=1 / 2$ for direct transition and $n=2$ for indirect transition.

Electrode Preparation and Photoelectrochemical Measurements. Electrodes of the various samples were prepared from bulk powder using spray-coating. Details of the preparation can be found elsewhere. ${ }^{51}$ The photoelectrochemical (PEC) measurements were performed in a classical one-compartment, three-electrode electrochemical cell ( $\mathrm{CH}$ Instruments, Model CHI720C). A Ag/AgCl/4 M $\mathrm{KCl}$ electrode was used as the reference and a $\mathrm{Pt}$ wire was used as the counterelectrode. All potentials in this study are reported versus the reversible hydrogen electrode according to eq 6 .

$$
\begin{aligned}
& \mathrm{E}_{\mathrm{RHE}}=\mathrm{E}_{\mathrm{Ag} / \mathrm{AgCl}}+0.0591 \mathrm{pH}+\mathrm{E}_{\mathrm{Ag} / \mathrm{AgCl}(4 \mathrm{M} \mathrm{KCl})}^{0} \\
& \mathrm{E}_{\mathrm{Ag} / \mathrm{AgCl}(4 \mathrm{M} \mathrm{KCl})}^{0}=0.1976 \mathrm{~V} \text { versus NHE at } 25^{\circ} \mathrm{C}
\end{aligned}
$$

A $400 \mathrm{~W}$ Xe-arc lamp (Newport) was used as the radiation source equipped with an IR filter. The incident light was adjusted to 1 Sun $\left(100 \mathrm{~mW} / \mathrm{cm}^{2}\right)$ at the surface of working electrode using a calibrated Si reference cell (Oriel). Photocurrent measurements were performed in $0.1 \mathrm{M}$ borate buffer $(\mathrm{pH} 9.2$ ) (in some cases with addition of $0.1 \mathrm{M}$ $\mathrm{Na}_{2} \mathrm{SO}_{3}$ ) with potential scan at $1 \mathrm{mV} \mathrm{s}^{-1}$ sweep rate.

Photoelectrochemical electrode stability tests employed chronoamperometric measurements at a fixed potential for $2 \mathrm{~h}$. The irradiation was blocked after each $30 \mathrm{~min}$ for a few seconds to confirm that dark current remained negligible. ICP-AES analysis of the electrolyte solution after the photostability experiment was performed using a Shimadzu ICPE-9000 instrument.

Kelvin-Probe Microscopy and Surface Photovoltage Spectroscopy. Measurements were performed using a KP Technology APS04 K-probe instrument. First, the Fermi level $\left(E_{\mathrm{F}}\right)$ of the $2 \mathrm{~mm}$ in diameter gold alloy-coated tip was determined by measuring the Fermi level of a silver reference target $\left(E_{\mathrm{F}, \mathrm{Au} \text { tip }}=-4.73 \mathrm{eV}\right)$. Thin films identical to those investigated in the PEC experiments were studied. The tip was vibrated over the sample surface at a fixed height $(\sim 1 \mathrm{~mm})$ and amplitude $(0.2 \mathrm{~mm})$ with a constant frequency (70 $\mathrm{Hz}$ ). Contact potential difference (CPD) was measured between the sample and the Kelvin probe tip after electrical equilibrium was reached. Surface photovoltage spectroscopy (SPV) data were recorded under ambient conditions. The vibrating Kelvin-probe tip functioned as the reference electrode. The samples were illuminated with a $150 \mathrm{~W}$ quartz halogen lamp (Fiber-Lite DC950) which was coupled to a monochromator.

Computational Methodology. The present calculations were performed using the density functional theory (DFT) $)^{52,53}$ as implemented in the Vienna $a b$ initio simulation package (VASP). ${ }^{54,55}$ Exchange and correlation were treated through the generalized gradient approximation (GGA) formalized by PerdewBurke-Ernzerhof (PBE). ${ }^{56}$ The projector augmented plane wave (PAW) method ${ }^{57}$ was used to treat the core electrons. The Monkhorst-Pack (MP) scheme was used to generate the k-points grid. In the present calculations, a $9 \times 9 \times 5$ k-point mesh for $\alpha$ $\mathrm{Cu}_{2} \mathrm{~V}_{2} \mathrm{O}_{7}$, a $9 \times 9 \times 7$ k-point mesh for $\beta-\mathrm{Cu}_{2} \mathrm{~V}_{2} \mathrm{O}_{7}$ and $\gamma-\mathrm{Cu}_{3} \mathrm{~V}_{2} \mathrm{O}_{8}$, and a $9 \times 7 \times 5$ k-point mesh for $\alpha-\mathrm{CuV}_{2} \mathrm{O}_{6}$ were used respectively for cell relaxation which gave well-converged results. A plane wave kinetic energy cutoff, $E_{\text {cut }}$ of $500 \mathrm{eV}$ for $\alpha-\mathrm{Cu}_{2} \mathrm{~V}_{2} \mathrm{O}_{7}, 550 \mathrm{eV}$ for $\beta$ $\mathrm{Cu}_{2} \mathrm{~V}_{2} \mathrm{O}_{7}, 600 \mathrm{eV}$ for $\gamma-\mathrm{Cu}_{3} \mathrm{~V}_{2} \mathrm{O}_{8}$, and $\alpha-\mathrm{CuV}_{2} \mathrm{O}_{6}$ were used respectively throughout the calculations. Effective $U$ values $\left(U_{\text {eff }}\right)$ of 3.1 and $5.0 \mathrm{eV}$ were used for the strongly correlated d electrons of $\mathrm{V}$ and $\mathrm{Cu}$, respectively. The visualization, VESTA, was used to visualize and analyze the crystal structure. ${ }^{58}$

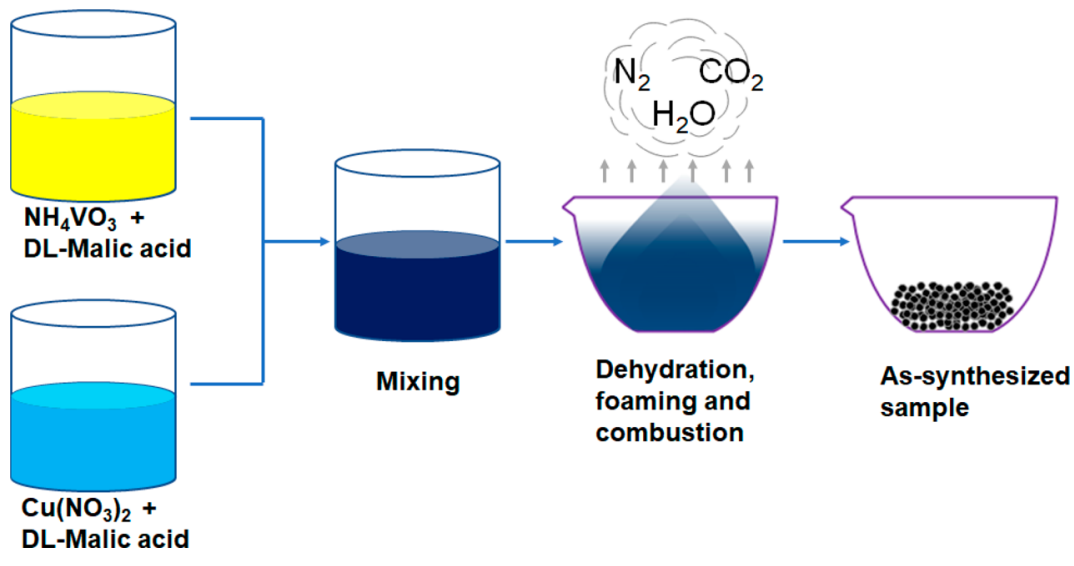

Figure 1. Schematic diagram of the solution combustion synthesis process. Refer to refs $1-4$ for further details. 


\section{RESULTS AND DISCUSSION}

Malic acid served as both fuel and chelating agent in the precursor mixture for SCS. A possible mechanism of complexation can be inferred from earlier reports. ${ }^{59,60}$ In this scheme, $\mathrm{Cu}\left(\mathrm{NO}_{3}\right)_{2}$ and $\mathrm{NH}_{4} \mathrm{VO}_{3}$ dissolved in the solution by forming their respective ions (eqs 7-8). Malic acid (MA) served as a chelating agent for these metal ions leading to the formation of a polymeric complex network (eq 9).

$$
\begin{aligned}
& \mathrm{Cu}\left(\mathrm{NO}_{3}\right)_{2} \rightarrow \mathrm{Cu}^{2+}+2 \mathrm{NO}_{3}^{-} \\
& \mathrm{NH}_{4} \mathrm{VO}_{3} \rightarrow \mathrm{NH}_{4}^{+}+\mathrm{VO}_{3}^{-} \\
& \mathrm{Cu}^{2+}-\mathrm{MA}+\mathrm{VO}_{3}^{-}-\mathrm{MA} \rightarrow-\mathrm{Cu}^{2+}-\mathrm{MA}-\mathrm{VO}_{3}^{-}-\mathrm{MA}-
\end{aligned}
$$

Once the ignition temperature was attained, combustion of MA led to thermal breakdown of the complex and culminated in oxide formation. The SCS process can be simulated ${ }^{61,62}$ by heating the precursor mixture in a TGA/DSC analysis environment; Figure 2 contains the TGA and DSC results for the formation of $\mathrm{CuV}_{2} \mathrm{O}_{6}$.

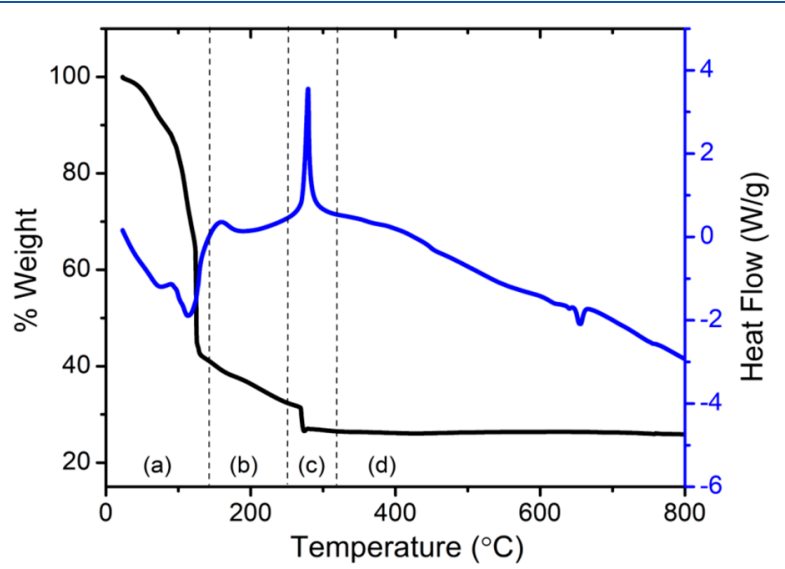

Figure 2. Simulation of solution combustion synthesis using TGA/ DSC analysis for $\mathrm{CuV}_{2} \mathrm{O}_{6}$.

The TGA/DSC trace can be divided into four distinct regions: (a) evaporation of water, (b) complexation of ions (see above) and removal of hydrated water, (c) ignition and combustion and, (d) removal of any carbonaceous remnant as well as product anneal. The first step was dehydration, which is an endothermic process and reflected in the DSC trace as a peak with negative heat flow. Once all the water evaporated, further heating caused removal of hydrated water and ionization-complexation of the precursor mixture which was then ignited (Region c) with a positive heat flow peak in DSC trace. In the case of $\mathrm{CuV}_{2} \mathrm{O}_{6}$, the ignition temperature appeared at $\sim 280{ }^{\circ} \mathrm{C}$. As the combustion reaction took place only for a short time (a few $\mathrm{min}$ ), the as-synthesized sample contained a mixture of amorphous and crystalline compounds which upon further heating yielded well-defined crystalline products (see below).

The effect of different anneal temperatures on the assynthesized $\mathrm{CuV}_{2} \mathrm{O}_{6}$ sample is presented in the XRD data in Figure 3a. Annealing at $550{ }^{\circ} \mathrm{C}$ showed a well-defined triclinic $\alpha-\mathrm{CuV}_{2} \mathrm{O}_{6}$ phase along with the minority phase, $\alpha-\mathrm{Cu}_{2} \mathrm{~V}_{2} \mathrm{O}_{7}$. Increasing the anneal temperature to $600{ }^{\circ} \mathrm{C}$ resulted in a diminution of the $\alpha-\mathrm{Cu}_{2} \mathrm{~V}_{2} \mathrm{O}_{7}$ phase. Further increasing the anneal temperature to $610{ }^{\circ} \mathrm{C}$ led to the formation of another compound in admixture, assigned as $\beta-\mathrm{CuV}_{2} \mathrm{O}_{6}$. Synthesis of $\alpha$ $\mathrm{CuV}_{2} \mathrm{O}_{6}$ using electrospray and sol-gel methods also reported mixed phase oxides ${ }^{14,15}$ presumably arising from their similar thermal history.

On the other hand, $\mathrm{Cu}_{2} \mathrm{~V}_{2} \mathrm{O}_{7}$ crystallized in two stable polymorphs, namely, low temperature $\beta-\mathrm{Cu}_{2} \mathrm{~V}_{2} \mathrm{O}_{7}$ (zeisite) and high temperature $\alpha-\mathrm{Cu}_{2} \mathrm{~V}_{2} \mathrm{O}_{7}$ (blossite) as shown in Figure 3b. Notably, these phases were pure unlike in the $\mathrm{CuV}_{2} \mathrm{O}_{6}$ case above. Thermal anneal at $500{ }^{\circ} \mathrm{C}$ for $1 \mathrm{~h}$ yielded a high purity $\beta$-polymorph which started transforming to $\alpha$-polymorph at higher temperatures; complete transformation occurred at 610 ${ }^{\circ} \mathrm{C}$. These observations on the SCS samples are consistent with earlier reports on $\mathrm{Cu}-\mathrm{V}-\mathrm{O}$ samples synthesized by other methods, which showed the $\beta$ to $\alpha$ transition at $605-610{ }^{\circ} \mathrm{C}$. ${ }^{19}$

The SCS of $\mathrm{Cu}_{3} \mathrm{~V}_{2} \mathrm{O}_{8}$ showed behavior contrasting the other two compounds with lower $\mathrm{Cu}$ content. The as-synthesized sample showed mostly the crystalline phase of $\gamma-\mathrm{Cu}_{3} \mathrm{~V}_{2} \mathrm{O}_{8}$ along with zeisite $\left(\beta-\mathrm{Cu}_{2} \mathrm{~V}_{2} \mathrm{O}_{7}\right)$ (Figure $3 \mathrm{c}$ ). Although we expected the formation of the low-temperature polymorph, $\beta$ $\mathrm{Cu}_{3} \mathrm{~V}_{2} \mathrm{O}_{8}$ (pseudolynsite), ${ }^{44}$ the formation of the hightemperature modification, $\gamma-\mathrm{Cu}_{3} \mathrm{~V}_{2} \mathrm{O}_{8}$, was presumably favored by the SCS environment. Once we annealed the as-synthesized sample, zeisite $\left(\beta-\mathrm{Cu}_{2} \mathrm{~V}_{2} \mathrm{O}_{7}\right)$ transformed to blossite ( $\alpha$ $\mathrm{Cu}_{2} \mathrm{~V}_{2} \mathrm{O}_{7}$ ). At $550{ }^{\circ} \mathrm{C}$ for $1 \mathrm{~h}, \gamma-\mathrm{Cu}_{3} \mathrm{~V}_{2} \mathrm{O}_{8}$ coexisted with both $\alpha$ - and $\beta-\mathrm{Cu}_{2} \mathrm{~V}_{2} \mathrm{O}_{7}$, whereas at $600{ }^{\circ} \mathrm{C}$ complete conversion of $\beta-\mathrm{Cu}_{2} \mathrm{~V}_{2} \mathrm{O}_{7}$ to $\alpha-\mathrm{Cu}_{2} \mathrm{~V}_{2} \mathrm{O}_{7}$ occurred. However, $\mathrm{Cu}_{2} \mathrm{~V}_{2} \mathrm{O}_{7}$ was always present in admixture with $\gamma-\mathrm{Cu}_{3} \mathrm{~V}_{2} \mathrm{O}_{8}$, a trend which also corroborates previous reports which show that $\gamma-\mathrm{Cu}_{3} \mathrm{~V}_{2} \mathrm{O}_{8}$ cannot be found as a single pure phase. ${ }^{25}$

Rietveld refinement was used to determine the crystal systems, unit cell parameters (Table S1), and compositions of different phases present in the SCS sample. Figure S1 represents the refinement of four compounds. For $\alpha$ $\mathrm{CuV}_{2} \mathrm{O}_{6}$, the XRD pattern of the sample annealed at $600{ }^{\circ} \mathrm{C}$ was employed for the refinement while the XRD pattern of $\gamma$ $\mathrm{Cu}_{3} \mathrm{~V}_{2} \mathrm{O}_{8}$ at $610{ }^{\circ} \mathrm{C}$ was used for refinement. More details on the refinement results are presented in Table S2.

Briefly, Rietveld refinements of the XRD data for the different copper vanadate samples indicated that in the case of $\alpha-\mathrm{CuV}_{2} \mathrm{O}_{6}$, there was a minority phase of $\alpha-\mathrm{Cu}_{2} \mathrm{~V}_{2} \mathrm{O}_{7}$ of $\sim 6.7 \%$. Similarly, $\beta-\mathrm{Cu}_{2} \mathrm{~V}_{2} \mathrm{O}_{7}$ showed two minority phases, $\alpha$ $\mathrm{Cu}_{2} \mathrm{~V}_{2} \mathrm{O}_{7}$ and $\alpha-\mathrm{CuV}_{2} \mathrm{O}_{6}$ to the extent of $\sim 3.0 \%$ and $\sim 6.5 \%$, respectively, along with the major phase $\beta-\mathrm{Cu}_{2} \mathrm{~V}_{2} \mathrm{O}_{7}$. The $\gamma$ $\mathrm{Cu}_{3} \mathrm{~V}_{2} \mathrm{O}_{8}$ sample also consisted of two minor phases, $\alpha$ $\mathrm{Cu}_{2} \mathrm{~V}_{2} \mathrm{O}_{7}(6.1 \%)$ and $\mathrm{Cu}_{11} \mathrm{~V}_{6} \mathrm{O}_{26}(7.0 \%)$. Figure $3 \mathrm{~d}$ shows the phase composition for the four SCS samples. Morphological characteristics of the annealed samples are presented in Figure S2; elemental analyses (via EDX) are contained in Figure S3 and Table S3.

Turning next to optical properties of the SCS samples, a structural analysis of the four copper vanadates was performed as a prelude to the DFT calculations. Figure 4 contains the structures on the left side panels. $\alpha-\mathrm{CuV}_{2} \mathrm{O}_{6}$ consists of $\mathrm{CuO}_{6}$ and $\mathrm{VO}_{6}$ octahedral layers (Figure 4a), while the crystal structures of $\alpha-\mathrm{Cu}_{2} \mathrm{~V}_{2} \mathrm{O}_{7}$ and $\beta-\mathrm{Cu}_{2} \mathrm{~V}_{2} \mathrm{O}_{7}$ (Figures $4 \mathrm{~b}, \mathrm{c}$ ) both share a common feature of $\mathrm{CuO}_{5}$ square pyramids connected by $\mathrm{V}_{2} \mathrm{O}_{7}$ (dimerization of two $\mathrm{VO}_{4}$ tetrahedra). On the other hand, $\gamma-\mathrm{Cu}_{3} \mathrm{~V}_{2} \mathrm{O}_{8}$ (Figure $4 \mathrm{~d}$ ) contains a network of two types of $\mathrm{Cu}$ motifs: $\mathrm{CuO}_{5}$ square-pyramids and $\mathrm{CuO}_{4}$ square-planar units that are cross-linked by $\mathrm{VO}_{4}$ tetrahedra. Similar structures may be found for $\alpha$-, $\beta$-, and $\gamma-\mathrm{Cu}_{2} \mathrm{~V}_{2} \mathrm{O}_{7}$ in ref 37 and for $\alpha$ $\mathrm{CuV}_{2} \mathrm{O}_{6}, \beta-\mathrm{Cu}_{2} \mathrm{~V}_{2} \mathrm{O}_{7}, \gamma-\mathrm{Cu}_{3} \mathrm{~V}_{2} \mathrm{O}_{8}$, and $\mathrm{Cu}_{11} \mathrm{~V}_{6} \mathrm{O}_{26}$ in ref 16 . 

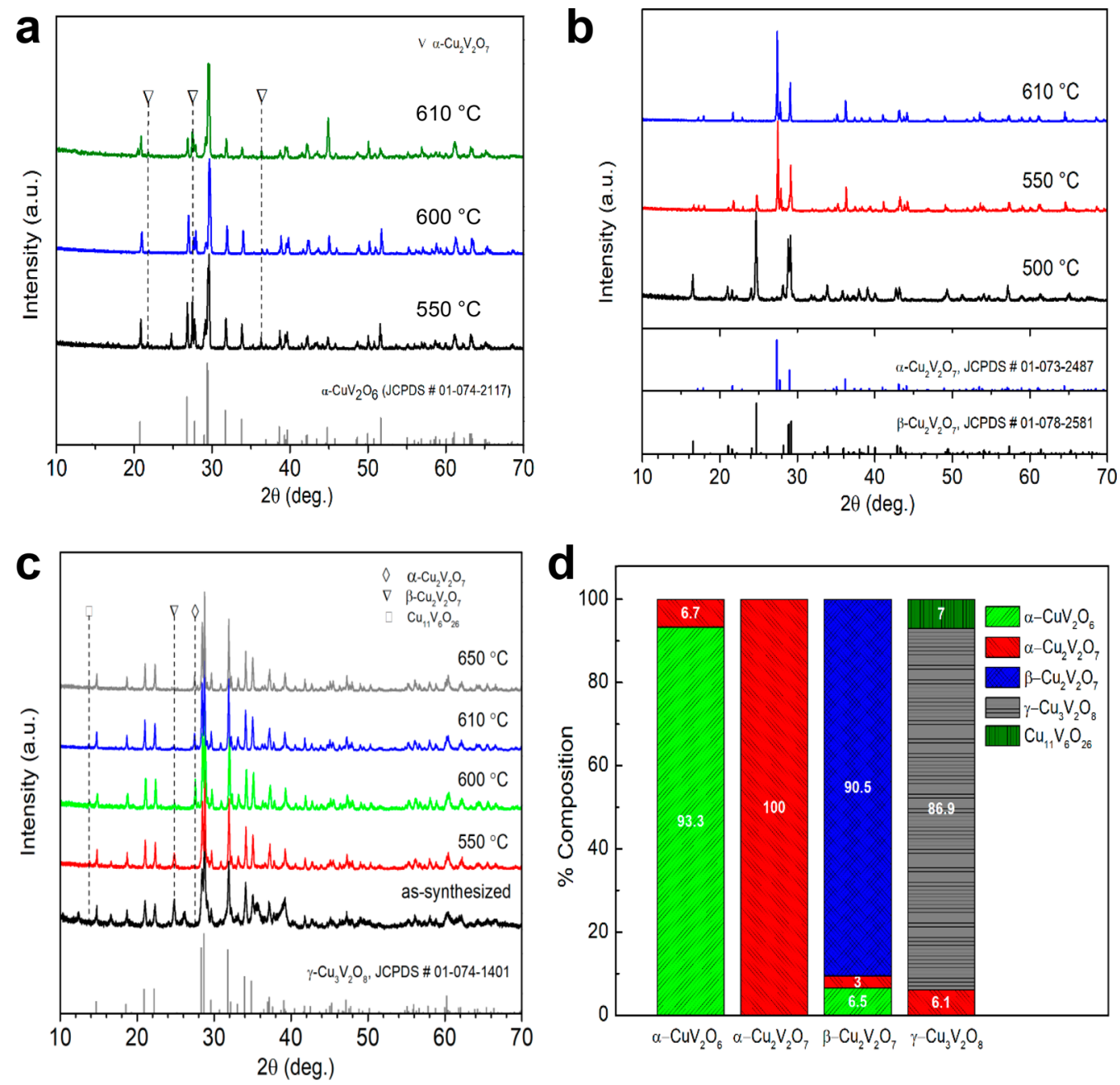

Figure 3. XRD-patterns of as-synthesized samples (a) $\mathrm{CuV}_{2} \mathrm{O}_{6}$, (b) $\mathrm{Cu}_{2} \mathrm{~V}_{2} \mathrm{O}_{7}$, (c) $\mathrm{Cu}_{3} \mathrm{~V}_{2} \mathrm{O}_{8}$, and (d) phase compositions from Rietveld refinement. In panels $\mathrm{a}-\mathrm{c}$, the minority components are marked with dashed lines.

The electronic band structures and the partial density of states (PDOS), as estimated using the DFT + U method, are shown in Figure 4 (right-hand panels, e-h) for the four different copper vanadates (i.e., $\alpha-\mathrm{CuV}_{2} \mathrm{O}_{6}, \alpha-\mathrm{Cu}_{2} \mathrm{~V}_{2} \mathrm{O}_{7}, \beta$ $\mathrm{Cu}_{2} \mathrm{~V}_{2} \mathrm{O}_{7}$, and $\gamma-\mathrm{Cu}_{3} \mathrm{~V}_{2} \mathrm{O}_{8}$, respectively.) Because the focus in this study was optical (rather than magnetic), no magnetic ordering was considered here unlike in the two precedent theoretical studies. As shown in the PDOS plots, all four phases have the V $3 \mathrm{~d}$ states at the conduction band minima and the valence band maxima is mostly $\mathrm{O} 2 \mathrm{p}$ and $\mathrm{Cu} 3 \mathrm{~d}$ states and they are strongly hybridized near the Fermi level. Furthermore, the Fermi level is dominated by $\mathrm{O} 2 \mathrm{p}$ states for $\alpha-\mathrm{CuV}_{2} \mathrm{O}_{6}, \beta-\mathrm{Cu}_{2} \mathrm{~V}_{2} \mathrm{O}_{7}$, and $\gamma-\mathrm{Cu}_{3} \mathrm{~V}_{2} \mathrm{O}_{8}$ while $\mathrm{Cu} 3 \mathrm{~d}$ states are the dominant contribution at the Fermi level for $\alpha$ $\mathrm{Cu}_{2} \mathrm{~V}_{2} \mathrm{O}_{7}$. These conclusions are in broad accord with the previous theoretical studies. ${ }^{16,39,47}$

For $\alpha-\mathrm{CuV}_{2} \mathrm{O}_{6}$ and $\gamma-\mathrm{Cu}_{3} \mathrm{~V}_{2} \mathrm{O}_{8}$, the bands were dispersive throughout all high symmetry points. For $\alpha-\mathrm{Cu}_{2} \mathrm{~V}_{2} \mathrm{O}_{7}$, the conduction band was less dispersive along the $\mathrm{Y} \rightarrow \mathrm{T} \rightarrow \mathrm{Z}$ direction and along $\mathrm{Al} \rightarrow \mathrm{Y}$ direction; both conduction and valence bands were less dispersive indicating the effective masses of the electrons and holes. For $\beta-\mathrm{Cu}_{2} \mathrm{~V}_{2} \mathrm{O}_{7}$, both conduction and valence bands were flat along the $\mathrm{X} \rightarrow \mathrm{Y} 1 \rightarrow$ $\mathrm{H} 1$ direction which also indicates that the carriers are "heavy." For all the copper vanadates studied, the valence band was composed of $\mathrm{Cu} 3 \mathrm{~d}$ and $\mathrm{O} 2 \mathrm{p}$ and the conduction band was mostly V $3 \mathrm{~d}$ states. Because the $\mathrm{d}-\mathrm{d}$ transition is forbidden, the transition is predicted to occur from occupied $O 2 p$ to unoccupied $\mathrm{V} 3 \mathrm{~d}$ states. It is worth noting here that among other copper vanadates $\alpha-\mathrm{CuV}_{2} \mathrm{O}_{6}$ would be a prominent photoabsorber because of its direct bandgap and dispersed band on both valence band maxima and conduction band minima.

All the copper vanadates in this study showed indirect bandgaps except $\alpha-\mathrm{CuV}_{2} \mathrm{O}_{6}$. The calculated indirect band gap values for $\alpha-\mathrm{Cu}_{2} \mathrm{~V}_{2} \mathrm{O}_{7}, \beta-\mathrm{Cu}_{2} \mathrm{~V}_{2} \mathrm{O}_{7}$, and $\gamma-\mathrm{Cu}_{3} \mathrm{~V}_{2} \mathrm{O}_{8}$ were 2.12, 2.28 , and $2.11 \mathrm{eV}$, respectively, whereas the direct band gap value for $\alpha-\mathrm{CuV}_{2} \mathrm{O}_{6}$ was $1.89 \mathrm{eV}$. Diffuse reflectance spectroscopy was employed to experimentally determine the absorbance coefficient of these oxides (c.f., Figure S4). While all the SCS samples strongly absorbed visible radiation, weak absorbance was detected below the absorption cutoff. Similar behavior was also found in the previous reports. ${ }^{25,26}$ The reason for the weak absorption is believed to be due to the onsite excitation of $\mathrm{d}$-shell electrons into the half-filled $\mathrm{Cu} \mathrm{d}_{x^{2}-y^{2}}$ orbitals of $\mathrm{Cu}^{2+} \cdot 25$

Previous theoretical and experimental studies suggested that all these oxides have indirect bandgaps. ${ }^{16,25}$ However, $\alpha$ $\mathrm{CuV}_{2} \mathrm{O}_{6}$ showed a direct transition in our theoretical study (see above) although the difference between indirect and 
a
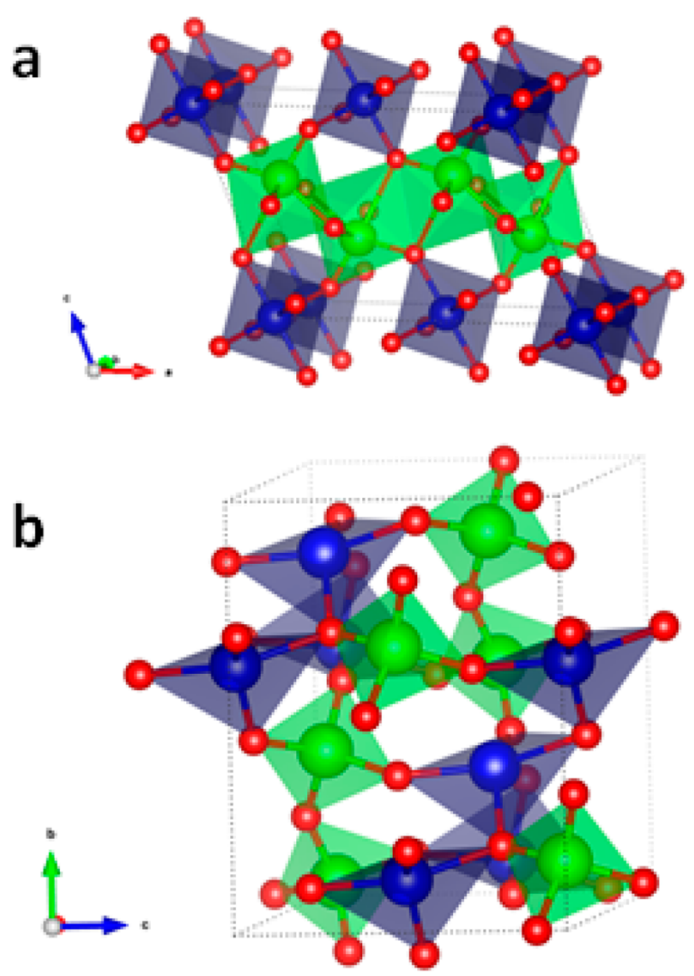

C
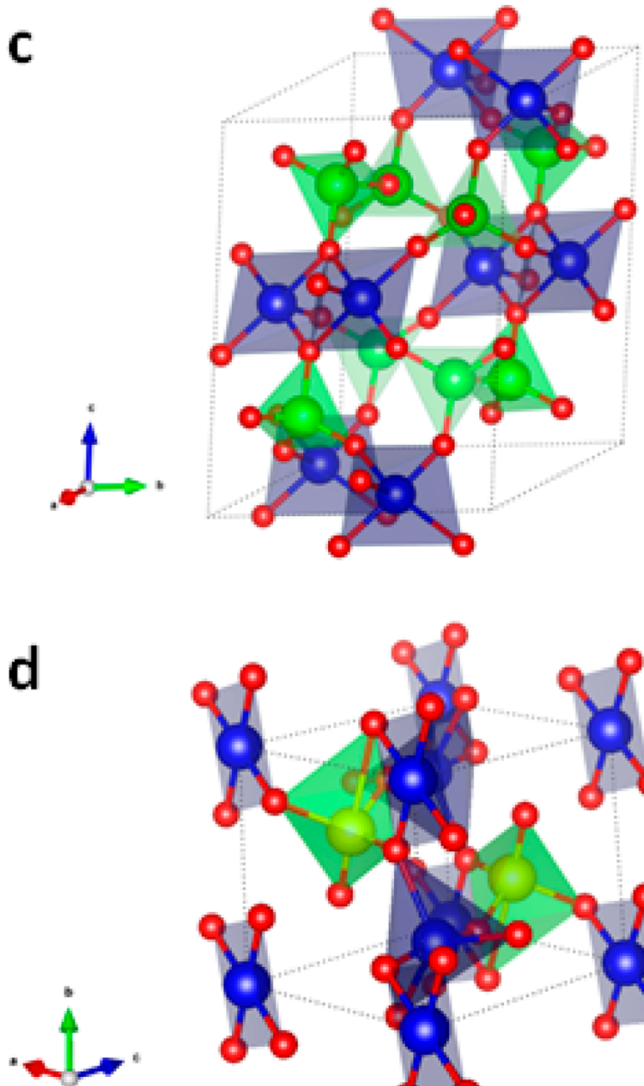

e

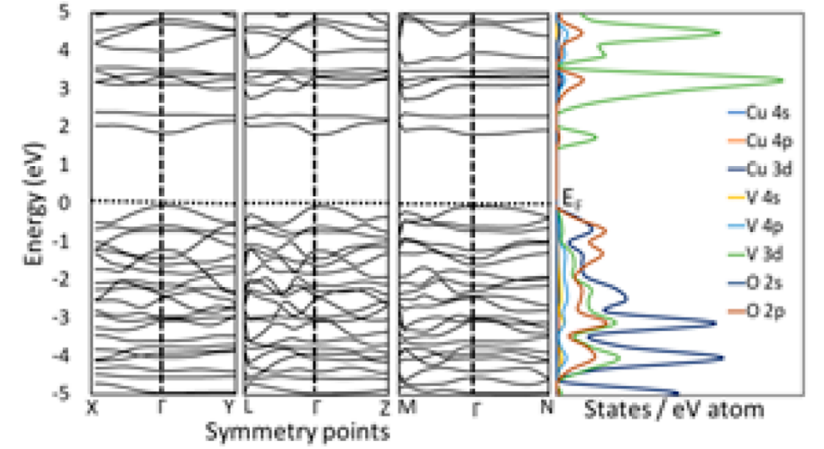

f

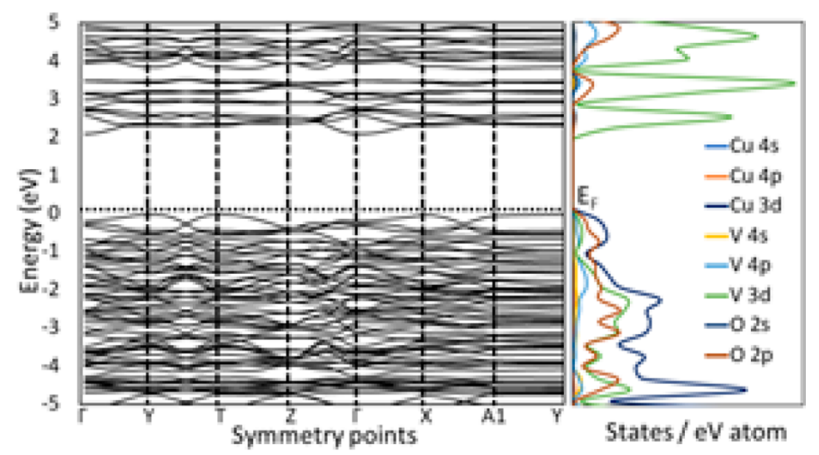

g

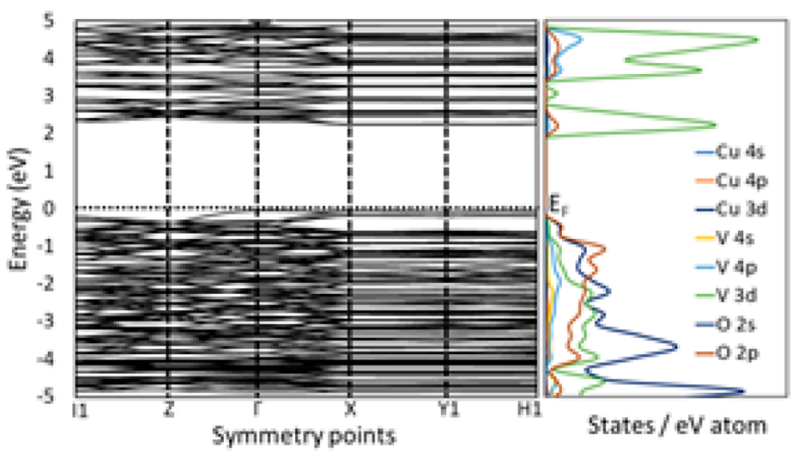

h

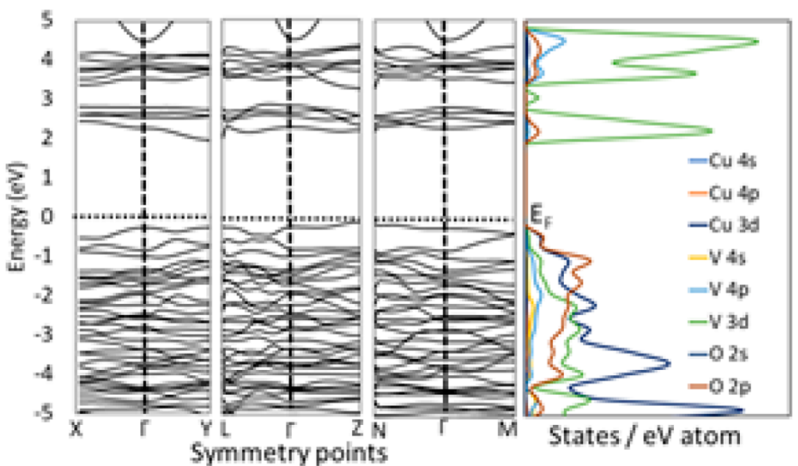

Figure 4. Chemical structures (panels $\mathrm{a}-\mathrm{d}$ ) and electronic band structures and density of states (DOS) (panels $\mathrm{e}-\mathrm{h})$ for $\alpha-\mathrm{CuV} \mathrm{O}_{6}(\mathrm{a}, \mathrm{e}), \alpha$ $\mathrm{Cu}_{2} \mathrm{~V}_{2} \mathrm{O}_{7}(\mathrm{~b}, \mathrm{f}), \beta-\mathrm{Cu}_{2} \mathrm{~V}_{2} \mathrm{O}_{7}(\mathrm{c}, \mathrm{g})$, and $\gamma-\mathrm{Cu}_{3} \mathrm{~V}_{2} \mathrm{O}_{8}(\mathrm{~d}, \mathrm{~h})$. The unit cells are shown on panels $\mathrm{a}-\mathrm{d}$ as dashed lines.

direct bandgaps was very low $(0.02 \mathrm{eV})$. Table 3 shows a comparison among the theoretical and experimental bandgaps along with the reported literature bandgaps. Clearly, our experimental bandgaps agree well with theoretically derived 
Table 3. Experimental and Calculated Bandgap Values ${ }^{a}$ along with Literature Data

\begin{tabular}{|c|c|c|c|c|c|c|}
\hline \multirow[b]{2}{*}{ oxide } & \multirow[b]{2}{*}{$E_{\mathrm{F}} / \mathrm{eV}$} & \multirow[b]{2}{*}{ theoretical bandgap $(\mathrm{eV})$} & \multicolumn{2}{|c|}{ experimental bandgap $(\mathrm{eV})$} & \multirow[b]{2}{*}{ reported experimental bandgap } & \multirow[b]{2}{*}{ refs } \\
\hline & & & DRS & SPS & & \\
\hline$\alpha-\mathrm{CuV}_{2} \mathrm{O}_{6}$ & -4.91 & 1.89 (direct) & 2.09 (direct) 2.07 & 1.76 & 1.96 & 10,12 \\
\hline$\alpha-\mathrm{Cu}_{2} \mathrm{~V}_{2} \mathrm{O}_{7}$ & -4.93 & 2.12 & 2.13 & 1.86 & $1.9 \pm 0.1$ & 16 \\
\hline$\beta-\mathrm{Cu}_{2} \mathrm{~V}_{2} \mathrm{O}_{7}$ & -4.85 & 2.28 & 2.22 & 1.94 & $2.0 \pm 0.2$ & 10,16 \\
\hline$\gamma-\mathrm{Cu}_{3} \mathrm{~V}_{2} \mathrm{O}_{8}$ & -4.89 & 2.11 & 2.18 & 1.73 & $1.8 \pm 0.1$ & 16,25 \\
\hline
\end{tabular}

${ }^{a}$ All the optical transitions are indirect unless otherwise noted.
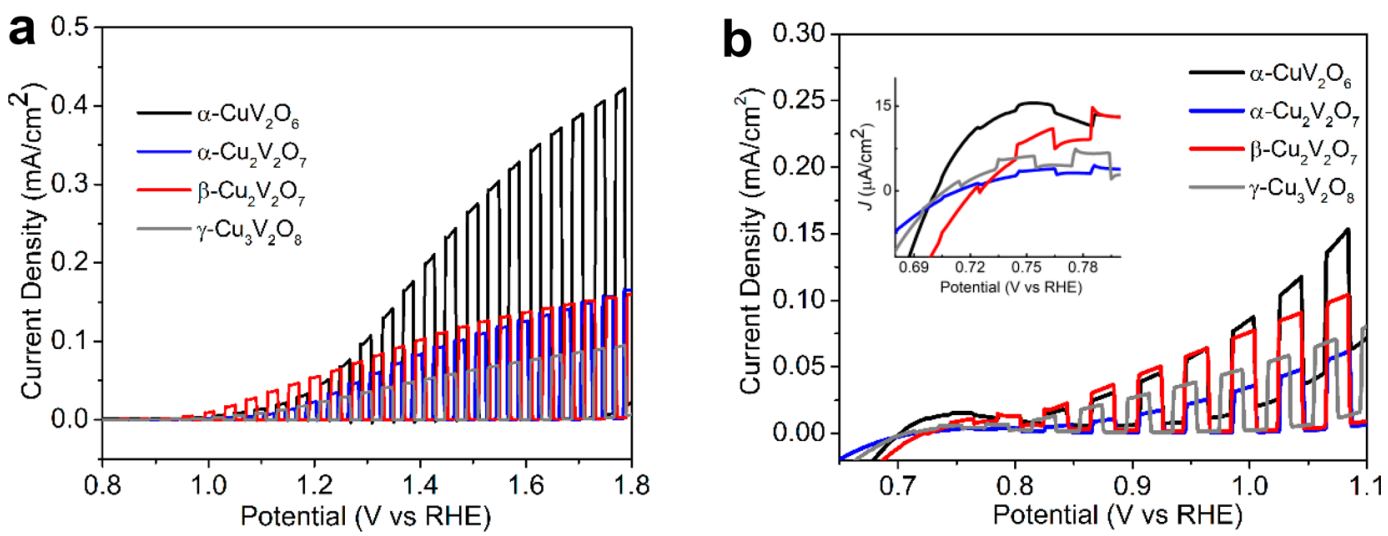

Figure 5. Photovoltammogram under interrupted irradiation of the samples (a) in $0.1 \mathrm{M}$ borate buffer solution ( $\mathrm{pH}=9.2$ ), (b) $0.1 \mathrm{M}$ borate buffer solution with $0.1 \mathrm{M} \mathrm{Na}_{2} \mathrm{SO}_{3}$ ( $\mathrm{pH}$ 9.2). All linear sweep voltammetry scans were performed under front side illumination with a scan rate of $1 \mathrm{mV} / \mathrm{s}$. Inset of (b) shows an extended view at the onset potential.

values as well as reported data in the literature on samples synthesized by other methods. The systematic discrepancy between the values derived from DRS and SPS (fourth and fifth columns in Table 3) will be addressed later.

The PEC activity of the four SCS-derived copper vanadate samples were evaluated using linear sweep voltammetry scan under chopped irradiation (Figure 5a). Sodium borate buffer $(0.1 \mathrm{M}, \mathrm{pH} \sim 9.2)$ was used as electrolyte due to improved stability of electrodes as suggested by previous reports. ${ }^{22,25}$ Linear sweep voltammograms were obtained sweeping the potentials from open circuit potential (OCP) to the positive directions. All four copper vanadates showed n-type photoactivity (positive photocurrents under reverse bias). Photocurrent onset potentials were found as $\sim 0.8 \mathrm{~V}$ versus RHE for all four copper vanadates. However, photocurrents were very low initially and slowly increased up to $1.0 \mathrm{~V}$ versus RHE. Beyond this value, the photocurrents increased gradually with applied positive bias and finally saturation of photocurrents was achieved.

Photocurrents (in $\mu \mathrm{A} / \mathrm{cm}^{2}$ ) at the thermodynamic oxidation potential of water (1.23 V versus $\mathrm{RHE})$ were found to be 55 , 30,65 , and 25 for $\alpha-\mathrm{CuV}_{2} \mathrm{O}_{6}, \alpha-\mathrm{Cu}_{2} \mathrm{~V}_{2} \mathrm{O}_{7}, \beta-\mathrm{Cu}_{2} \mathrm{~V}_{2} \mathrm{O}_{7}$, and $\gamma$ $\mathrm{Cu}_{3} \mathrm{~V}_{2} \mathrm{O}_{8}$ respectively. Admittedly, these photocurrents were quite low; however, some of these values $\left(55 \mu \mathrm{A} / \mathrm{cm}^{2}\right.$ for $\alpha$ $\mathrm{CuV}_{2} \mathrm{O}_{6}$ and $65 \mu \mathrm{A} / \mathrm{cm}^{2}$ for $\left.\beta-\mathrm{Cu}_{2} \mathrm{~V}_{2} \mathrm{O}_{7}\right)$ are 2-fold higher than the maximum reported photocurrent $\left(25 \mu \mathrm{A} / \mathrm{cm}^{2}\right.$ for $\alpha$ $\mathrm{CuV}_{2} \mathrm{O}_{6}$ and $35 \mu \mathrm{A} / \mathrm{cm}^{2}$ for $\left.\beta-\mathrm{Cu}_{2} \mathrm{~V}_{2} \mathrm{O}_{7}\right)$ under similar conditions. ${ }^{10}$ These improved photocurrents are attributed to better crystallinity of these SCS-derived oxides as inferred from their XRD patterns. An alternative possibility is the presence of more oxygen vacancies in the samples, although this requires further experimental verification, beyond the scope of the present study.
Interestingly $\alpha-\mathrm{CuV}_{2} \mathrm{O}_{6}$ showed very little photocurrent at low applied bias, however, the photocurrent increased drastically with applied bias more than $1.2 \mathrm{~V}$ versus RHE and attained a maximum value of $\sim 400 \mu \mathrm{A} / \mathrm{cm}^{2}$ at $1.8 \mathrm{~V}$ versus RHE which is more than 2-fold higher than the other copper vanadates. A previous study ${ }^{28}$ showed that surface states in $\mathrm{Cu}$ rich vanadates are responsible for electron-hole recombination; this would be in line with the good performance noted here with the $\mathrm{Cu}-\mathrm{lean}$ vanadate sample. However, the exceptional high photocurrent of $\alpha-\mathrm{CuV}_{2} \mathrm{O}_{6}$ can also be correlated with its electronic band structure (see Figure 4e) that shows a direct bandgap.

Moreover, the coordination of $\mathrm{Cu}$ and $\mathrm{V}$ in $\alpha$ $\mathrm{CuV}_{2} \mathrm{O}_{6}\left(\mathrm{CuO}_{6}\right.$ and $\mathrm{VO}_{6}$ octahedra) are different from the other three copper vanadates $\left(\mathrm{CuO}_{5}\right.$ square-pyramid and/or $\mathrm{CuO}_{4}$ square-planar and $\mathrm{VO}_{4}$ tetrahedra) and hybridize differently. This structural nuance could contribute to a higher mobility of minority carriers through the $\alpha-\mathrm{CuV}_{2} \mathrm{O}_{6}$ crystal lattice although a separate (solid-state transport) study (beyond the scope of this work) is required to validate this presumption.

Because of the sluggish kinetics of these oxides to water oxidation, photocurrent onset potentials were obtained from sulfite (a kinetically fast hole acceptor) oxidation with the addition of $0.1 \mathrm{M} \mathrm{Na}_{2} \mathrm{SO}_{3}$ to the $0.1 \mathrm{M}$ borate buffer; these data are shown in Figure $5 \mathrm{~b}$. The potentials were swept from a value, a little negative of the rest (open circuit) valuei in a positive direction to accurately record the photocurrent onset potentials (see inset in Figure 5b) The onset of photocurrents shifted toward more negative direction than water oxidation consistent with a previous report. ${ }^{10,22,25}$ The onset potentials were found to be $0.72,0.70,0.69$, and $0.66 \mathrm{~V}$ versus RHE for $\alpha-\mathrm{CuV}_{2} \mathrm{O}_{6}, \alpha-\mathrm{Cu}_{2} \mathrm{~V}_{2} \mathrm{O}_{7}, \beta-\mathrm{Cu}_{2} \mathrm{~V}_{2} \mathrm{O}_{7}$, and $\gamma-\mathrm{Cu}_{3} \mathrm{~V}_{2} \mathrm{O}_{8}$ respectively. Approximating these onset potentials as the flat-band 
potentials afford estimates of the $E_{\mathrm{F}}$ levels of these oxides. As the conduction band is a few hundred millivolts more negative than the Fermi level, ${ }^{63}$ all these oxides have conduction band minima in the range of $0.65-70 \mathrm{~V}$ versus RHE (Figure 6) in line with reported values. ${ }^{10,22,25}$

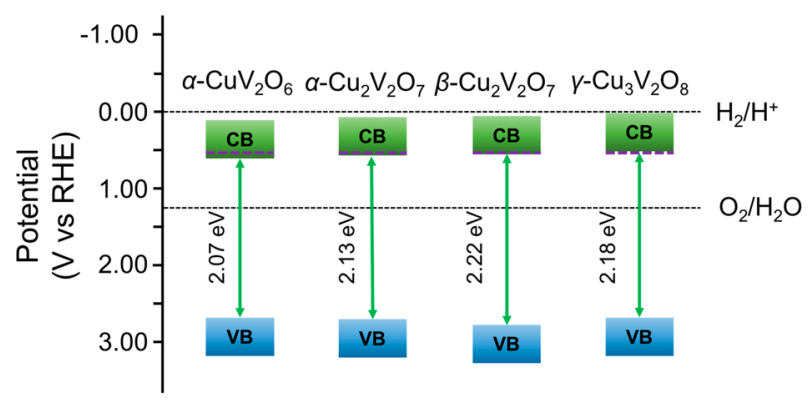

Figure 6. Band-edge positions based on experimental photocurrent onsets for the four copper vanadate samples considered in this study. Purple dashed lines show Fermi levels derived from the contact potential difference measurement.

Importantly, note that none of the copper vanadate samples in this study are thermodynamically capable of generating hydrogen from water. This is seen from the fact that the Fermi levels in all the cases lie positive of the hydrogen evolution potential (Figure 6). On the other hand, the photogenerated holes in all the cases will have sufficient energy to oxidize water.

The relative insensitivity of the band edge positions as a function of chemical composition in the $\mathrm{Cu}-\mathrm{V}-\mathrm{O}$ system deserves comment. Scrutiny of the conduction band edge position does reveal a slight but systematic shift with greater $\mathrm{Cu} / \mathrm{V}$ ratio: $0.72,0.70,0.69$, and $0.66 \mathrm{~V}$ versus $\mathrm{RHE}$ for $\alpha$ $\mathrm{CuV}_{2} \mathrm{O}_{6}, \alpha-\mathrm{Cu}_{2} \mathrm{~V}_{2} \mathrm{O}_{7}, \beta-\mathrm{Cu}_{2} \mathrm{~V}_{2} \mathrm{O}_{7}$, and $\gamma-\mathrm{Cu}_{3} \mathrm{~V}_{2} \mathrm{O}_{8}$, respectively. On the other hand, the valence band edge of $\mathrm{V}_{2} \mathrm{O}_{5}$ is derived from $\mathrm{O} 2 \mathrm{p}$ orbitals and lies at $\sim 3.0 \mathrm{~V}$ versus NHE. On incorporation of $\mathrm{Cu}, \mathrm{Cu} 3 \mathrm{~d}^{9}$ hybridizes with $\mathrm{O} 2 \mathrm{p}$ and "lifts" the valence band edge to $\sim 2.6 \mathrm{~V}$ versus NHE. However, the conduction band edges of both $\mathrm{V}_{2} \mathrm{O}_{5}$ and copper vanadates are made of $\mathrm{V} 3 \mathrm{~d}$ orbitals and hence they lie in similar positions (0.5-0.6 V versus NHE).

The optoelectronic properties were further investigated with Kelvin-probe measurements and surface photovoltage spectroscopy (Figure $7 \mathrm{a}, \mathrm{b}$ ). The $E_{\mathrm{F}}$ of the various copper vanadate samples were estimated from their contact potential differences (CPD), Figure 7a. The purple dashed lines in Figure 6 show the corresponding $E_{\mathrm{F}}$ for each oxide which lie close to the flatband potential values, determined from the photovoltammograms (see Figure 5), as expected for reasonably doped n-type semiconductors.

The wavelength-dependence of light driven charge separation was monitored by SPV measurements. All spectra show negative photovoltage values (Figure $7 \mathrm{~b}$ ), which can be associated with the transfer of electrons to the ITO layer. ${ }^{64}$ These data show (and corroborate the trends in Figure 5) that all samples behave as n-type semiconductors. ${ }^{64-66}$ The highest photovoltage was recorded in the case of the $\gamma-\mathrm{Cu}_{3} \mathrm{~V}_{2} \mathrm{O}_{8}$ sample $(\approx-130 \mathrm{mV})$. Interestingly, this trend was not reflected by the photovoltammograms where $\gamma-\mathrm{Cu}_{3} \mathrm{~V}_{2} \mathrm{O}_{8}$ gave the lowest photocurrents. Since the buildup of photovoltage is connected to both charge separation and transport in the electrode bulk, these data suggest that the reason behind the poor PEC performance is rooted in the sluggish water/sulfite oxidation kinetics on the surface.

Bandgap values $\left(E_{\mathrm{BG}}\right)$ were determined from the photovoltage onset on the SPV spectra (Table 3). These are consistently lower than the values derived from our diffuse reflectance spectroscopy data, but much closer to those reported in the literature. These systematic differences are possibly linked to the higher sensitivity of SPV to sub-bandgap transitions ${ }^{67}$ and to the bandwidth of the monochromatic light (i.e., $40 \mathrm{~nm}$ ).

Finally, the PEC stability of three SCS-derived copper vanadate samples with increasing $\mathrm{Cu} / \mathrm{V}$ ratio, was compared (Figure 8). These chronoamperometric data pertain to a fixed potential of $1.4 \mathrm{~V}$ versus RHE under $100 \mathrm{~mW} / \mathrm{cm}^{2}$ irradiation. The photocurrent for the $\alpha-\mathrm{CuV}_{2} \mathrm{O}_{6}$ sample decreased sharply at the beginning and $\sim 30 \%$ of the photocurrent loss took place during the first $30 \mathrm{~min}$. After that time frame, the photocurrent appeared quite stable for at least another $2 \mathrm{~h}$ at which time the experiment was discontinued (black curve, Figure 8). On the other hand, the photocurrent for $\beta-\mathrm{Cu}_{2} \mathrm{~V}_{2} \mathrm{O}_{7}$ showed a sharp fall during the first $5 \mathrm{~min}$, then slowly decreased and $20 \%$ of photocurrent was lost after $2 \mathrm{~h}$ (red curve, Figure 8). In contrast, photocurrent loss for $\gamma-\mathrm{Cu}_{3} \mathrm{~V}_{2} \mathrm{O}_{8}$ was negligible after $2 \mathrm{~h}$.

Importantly, this study shows that a higher $\mathrm{Cu} / \mathrm{V}$ ratio in the copper vanadate compositions renders better PEC stability for the corresponding oxide. We attribute the sharp loss of
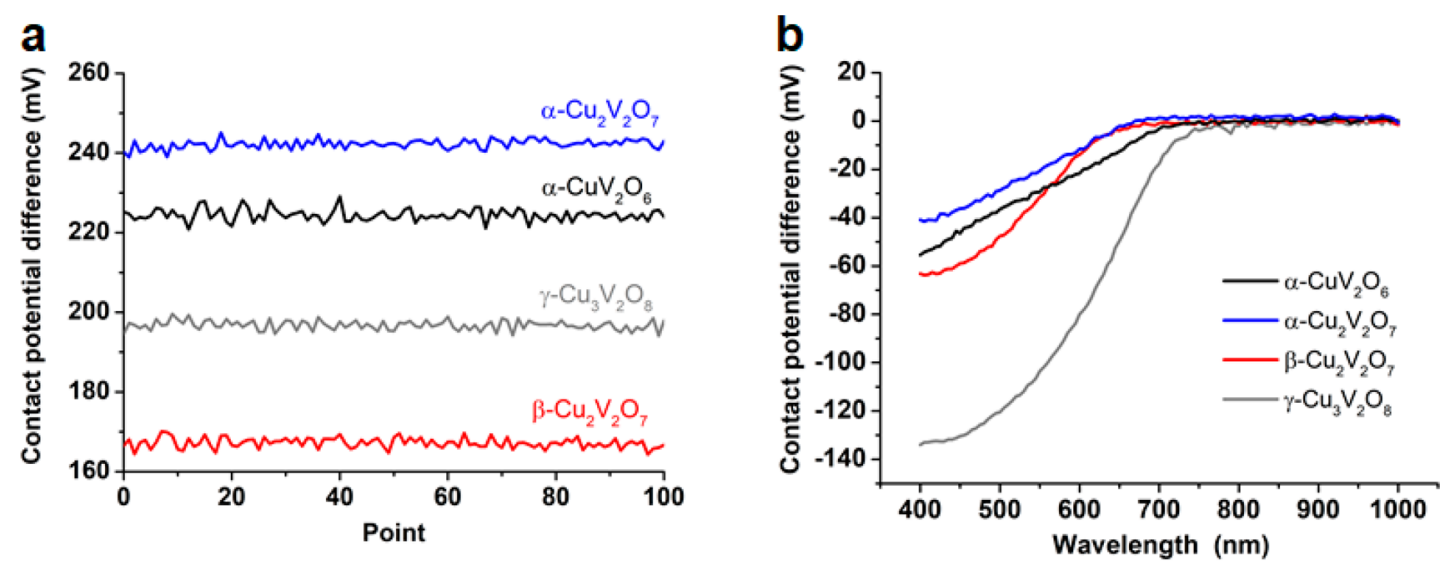

Figure 7. Contact potential difference (CPD) (a) and surface photovoltage spectra (b) for the four copper vanadate samples. 


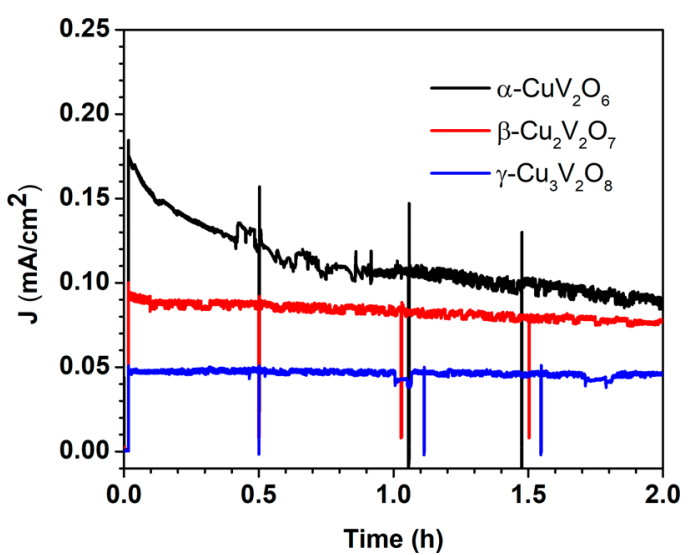

Figure 8. Chronoamperometric measurements of copper vanadates at $1.4 \mathrm{~V}$ versus RHE in $0.1 \mathrm{M}$ sodium borate buffer $(\mathrm{pH} 9.2)$ under 100 $\mathrm{mW} / \mathrm{cm}^{2}$ irradiation.

photocurrent for $\alpha-\mathrm{CuV}_{2} \mathrm{O}_{6}$ to initial photoleaching of vanadium leaving behind a $\mathrm{CuO}$ layer on the surface. ${ }^{68}$ Thus, $\mathrm{CuO}$ acts as a passive layer for the film, suppressing further corrosion of vanadium from the bulk matrix. ${ }^{68}$ Accordingly, the $\mathrm{V} / \mathrm{Cu}$ ratio in the electrolyte solution after the stability experiment was analyzed using ICP-AES which confirmed the presence of four-times higher $\mathrm{V}$ than $\mathrm{Cu}$ in the solution. This observation is entirely consistent with the stabilization mechanism proposed by previous authors. ${ }^{68}$

\section{CONCLUSIONS}

The main contribution of the present study and its differentiator from the considerable number of reports that have emerged on copper vanadates is the demonstration that a range of molar stoichiometries from $1: 1$ to $3: 1$ in this compound family can be derived simply by tuning the precursor mole ratio in the solution combustion synthesis procedure. Importantly, SCS is very time-efficient and the various compositions can be obtained in a matter of minutes (as opposed to hours or even days in classical solution-based or ceramic synthesis routes, Table 1). In this regard, SCS is eminently suited for incorporation into the high throughput screening methods ${ }^{16,27}$ that have been deployed for the $\mathrm{Cu}-$ $\mathrm{V}-\mathrm{O}$ family of n-type semiconductors. A secondary feature of this study is that it builds upon the corpus of structural, electronic, and optoelectronic body of information on copper vanadates, derived from a variety of synthetic procedures (c.f., Table 1). While a number of attributes of these family of compounds are appealing from a solar fuels materials design perspective, their charge transport characteristics (limited by small-polaron hopping $)^{69}$ certainly would need further optimization, beyond the scope of this particular study.

\section{ASSOCIATED CONTENT}

\section{S Supporting Information}

The Supporting Information is available free of charge on the ACS Publications website at DOI: 10.1021/acsaem.9b00179.

Rietveld refinement of XRD data for $\alpha-\mathrm{CuV}_{2} \mathrm{O}_{6}, \beta$ $\mathrm{Cu}_{2} \mathrm{~V}_{2} \mathrm{O}_{7}, \gamma-\mathrm{Cu}_{2} \mathrm{~V}_{2} \mathrm{O}_{7}$, and $\alpha-\mathrm{Cu}_{3} \mathrm{~V}_{2} \mathrm{O}_{8}, \mathrm{SEM}$ and energy dispersive $\mathrm{X}$-ray analysis $(\mathrm{EDX})$ data, $\mathrm{V} / \mathrm{Cu}$ ratios for the various samples, diffuse reflectance spectra (PDF)

\section{AUTHOR INFORMATION}

\section{Corresponding Author}

*E-mail: rajeshwar@uta.edu.

ORCID $\odot$

Robin T. Macaluso: 0000-0002-0021-0775

Mohammad N. Huda: 0000-0002-2655-498X

Csaba Janáky: 0000-0001-5965-5173

Krishnan Rajeshwar: 0000-0003-4917-7790

Notes

The authors declare no competing financial interest.

\section{ACKNOWLEDGMENTS}

C.J. and A.K. acknowledge the support of the "Széchenyi 2020" program within the framework of the GINOP-2.3.2-15-201600013 project. M.T.G. and C.L. acknowledge CAPES-PDSE (Process \#88881.131530/2016-0) for partial financial support under the Coordenação de Aperfeiçoamento de Pessoal de Nivel Superior Program. M.N.H. was supported by the National Science Foundation (Award No. DMR-1609811). M.N.H. and H.P.S. thank the Texas Advanced Computing Center (Austin, TX) facility for their computational needs. The authors thank the three anonymous reviewers for perceptive comments on an earlier version of this manuscript.

\section{REFERENCES}

(1) Merzhanov, A. G. The Chemistry of Self-Propagating HighTemperature Synthesis. J. Mater. Chem. 2004, 14, 1779-1786.

(2) Rajeshwar, K.; de Tacconi, N. R.; Chanmanee, W. Combustion Synthesis of Oxide Semiconductors for Solar Energy Conversion and Environmental Remediation. Chem. Soc. Rev. 2009, 38, 1984-1998.

(3) Hossain, M. K.; Kecsenovity, E.; Varga, A.; Molanar, M.; Janaky, C.; Rajeshwar, K. Solution Combustion Synthesis of Complex Oxide Semiconductors. Int. J. Self-Propag. High-Temp. Synth. 2018, 27, 129140.

(4) Li, F. T.; Ran, J.; Jaroniec, M.; Qiao, S. Z. Solution Combustion Synthesis of Metal Oxide Nanomaterials for Energy Storage and Conversion. Nanoscale 2015, 7, 17590-17610.

(5) Wen, W.; Wu, J. M. Nanomaterials via Solution Combustion Synthesis: A Step Nearer to Controllability. RSC Adv. 2014, 4, 58090-58100.

(6) Solar Hydrogen Generation: Toward a Renewable Energy Future; Rajeshwar, K., McConnell, R., Licht, S., Eds.; Kluwer Academic: New York, 2008.

(7) Rajeshwar, K. Photoelectrochemistry and the Environment. J. Appl. Electrochem. 1995, 25, 1067-1082.

(8) Rajeshwar, K.; Hossain, M. K.; Macaluso, R. T.; Janáky, C.; Varga, A.; Kulesza, P. J. Copper Oxide-Based Ternary and Quaternary Oxides: Where Solid-State Chemistry Meets Solar Fuels. J. Electrochem. Soc. 2018, 165, H3192-H3206.

(9) Hillel, T.; Ein-Eli, Y. Copper Vanadate as Promising High Voltage Cathodes for Li Thermal Batteries. J. Power Sources 2013, $229,112-116$.

(10) Guo, W.; Chemelewski, W. D.; Mabayoje, O.; Xiao, P.; Zhang, Y.; Mullins, C. B. Synthesis and Characterization of $\mathrm{CuV}_{2} \mathrm{O}_{6}$ and $\mathrm{Cu}_{2} \mathrm{~V}_{2} \mathrm{O}_{7}$ Two Photoanode Candidates for Photoelectrochemical Water Oxidation. J. Phys. Chem. C 2015, 119, 27220-27227.

(11) Newhouse, P. F.; Boyd, D. A.; Shinde, A.; Guevarra, D.; Zhou, L.; Soedarmadji, E.; Li, G.; Neaton, J. B.; Gregoire, J. M. Solar Fuel Photoanodes Prepared by Inkjet Printing of Copper Vanadates. J. Mater. Chem. A 2016, 4, 7483-7494.

(12) Khan, I.; Qurashi, A. Shape Controlled Synthesis of Copper Vanadate Platelet Nanostructures, Their Optical Band Edges, and Solar-Driven Water Splitting Properties. Sci. Rep. 2017, 7, 14370. 
(13) Cao, J. Q.; Wang, X. Y.; Tang, A.; Wang, X.; Wang, Y.; Wu, W. Sol-gel Synthesis and Electrochemical Properties of $\mathrm{CuV}_{2} \mathrm{O}_{6}$ Cathode Material. J. Alloys Compd. 2009, 479, 875-878.

(14) Kim, M. W.; Joshi, B.; Yoon, H.; Ohm, T. Y.; Kim, K.; AlDeyab, S. S.; Yoon, S. S. Electrosprayed Copper Hexaoxodivanadate $\left(\mathrm{CuV}_{2} \mathrm{O}_{6}\right)$ And Pyrovanadate $\left(\mathrm{Cu}_{2} \mathrm{~V}_{2} \mathrm{O}_{7}\right)$ Photoanodes for Efficient Solar Water Splitting. J. Alloys Compd. 2017, 708, 444-450.

(15) Ma, H.; Zhang, S.; Ji, W.; Tao, Z.; Chen, J. $\alpha-\mathrm{CuV}_{2} \mathrm{O}_{6}$ Nanowires: Hydrothermal Synthesis and Primary Lithium Battery Application. J. Am. Chem. Soc. 2008, 130, 5361-5367.

(16) Zhou, L.; Yan, Q.; Shinde, A.; Guevarra, D.; Newhouse, P. F.; Becerra-Stasiewicz, N.; Chatman, S. M.; Haber, J. A.; Neaton, J. B.; Gregoire, J. M. High Throughput Discovery of Solar Fuels Photoanodes in the CuO- $\mathrm{V}_{2} \mathrm{O}_{5}$ System. Adv. Energy Mater. 2015, 5, 1500968.

(17) $\mathrm{He}, \mathrm{Z}$.; Ueda, Y. Flux Growth of $\beta-\mathrm{Cu}_{2} \mathrm{~V}_{2} \mathrm{O}_{7}$ Single Crystals in a Closed Crucible. Cryst. Growth Des. 2008, 8, 2223-2226.

(18) Clark, G. M.; Garlick, R. Formation and Properties of Copper (II) Divanadate (V). J. Inorg. Nucl. Chem. 1978, 40, 1347-1349.

(19) Slobodin, B. V.; Surat, L. L.; Samigullina, R. F. Polymorphism in Copper Pyrovanadate. Russ. J. Inorg. Chem. 2009, 54, 797-802.

(20) Rogado, N.; Haas, M. K.; Lawes, G.; Huse, D. A.; Ramirez, A. P.; Cava, R. J. $\beta-\mathrm{Cu}_{3} \mathrm{~V}_{2} \mathrm{O}_{8}$ Magnetic Ordering in a Spin-1/2 KagoméStaircase Lattice. J. Phys.: Condens. Matter 2003, 15, 907-914.

(21) Wang, M.; Liu, Q. Synthesis and Photocatalytic Property of $\mathrm{Cu}_{3} \mathrm{~V}_{2} \mathrm{O}_{8}$ Prepared by Liquid Phase Precipitation. Adv. Mater. Res. 2011, 236, 1675-1678.

(22) Seabold, J. A.; Neale, N. R. All First Row Transition Metal Oxide Photoanode for Water Splitting Based on $\mathrm{Cu}_{3} \mathrm{~V}_{2} \mathrm{O}_{8}$. Chem. Mater. 2015, 27, 1005-1013.

(23) Zhang, S.; Sun, Y.; Li, C.; Ci, L. $\mathrm{Cu}_{3} \mathrm{~V}_{2} \mathrm{O}_{8}$ Hollow Spheres in Photocatalysis and Primary Lithium Batteries. Solid State Sci. 2013, $25,15-21$.

(24) Li, M.; Gao, Y.; Chen, N.; Meng, X.; Wang, C.; Zhang, Y.; Zhang, D.; Wei, Y.; Du, F.; Chen, G. $\mathrm{Cu}_{3} \mathrm{~V}_{2} \mathrm{O}_{8}$ Nanoparticles as Intercalation-Type Anode Material for Lithium-Ion Batteries. Chem. Eur. J. 2016, 22, 11405-11412.

(25) Jiang, C. M.; Farmand, M.; Wu, C. H.; Liu, Y. S.; Guo, J.; Drisdell, W. S.; Cooper, J. K.; Sharp, I. D. Electronic Structure, Optoelectronic Properties, and Photoelectrochemical Characteristics of $\gamma-\mathrm{Cu}_{3} \mathrm{~V}_{2} \mathrm{O}_{8}$ Thin Films. Chem. Mater. 2017, 29, 3334-3345.

(26) Lumley, M. A.; Choi, K.-S. Investigation of Pristine and (Mo, W)-Doped $\mathrm{Cu}_{11} \mathrm{~V}_{6} \mathrm{O}_{26}$ for Use as Photoanodes for Solar Water Splitting. Chem. Mater. 2017, 29, 9472-9479.

(27) Yan, Q.; Yu, J.; Suram, S. K.; Zhou, L.; Shinde, A.; Newhouse, P. F.; Chen, W.; Li, G.; Persson, K. A.; Gregoire, J. M.; Neaton, J. B. Solar Fuels Photoanode Materials Discovery by Integrating HighThroughput Theory and Experiment. Proc. Natl. Acad. Sci. U. S. A. 2017, 114, 3040-3043.

(28) Jiang, C.-M.; Segev, G.; Hess, L. H.; Liu, G.; Zaborski, G.; Toma, F. M.; Cooper, J. K.; Sharp, I. D. Composition-Dependent Functionality of Copper Vanadate Photoanodes. ACS Appl. Mater. Interfaces 2018, 10, 10627-10633.

(29) Cardenas-Morcoso, D.; Peiro-Franch, A.; Herraiz-Cardona, I.; Gimenez, S. Chromium Doped Copper Vanadate Photoanodes for Water Splitting. Catal. Today 2017, 290, 65-72.

(30) Brisi, C.; Molinari, A. Sistema Osido Ramicoanidride Vanadica. Ann. Chim. 1958, 48, 263-269.

(31) Fleury, P. The CuO- $\mathrm{V}_{2} \mathrm{O}_{5}$ System. Compt Rend Acad. Sci. 1966, $265,1375-1377$.

(32) Shannon, R. D.; Calvo, C. Crystal Structure of a New Form of $\mathrm{Cu}_{3} \mathrm{~V}_{2} \mathrm{O}_{8}$. Can. J. Chem. 1972, 50, 3944-3949.

(33) Cao, X.; Xie, J.; Zhan, H.; Zhou, Y. Synthesis of $\mathrm{CuV}_{2} \mathrm{O}_{6}$ as a Cathode Material for Rechargeable Lithium Batteries from $\mathrm{V}_{2} \mathrm{O}_{5}$ Gel. Mater. Chem. Phys. 2006, 98, 71-75.

(34) Zhang, S.; Ci, L.; Liu, H. Synthesis, Characterization, and Electrochemical Properties of $\mathrm{Cu}_{3} \mathrm{~V}_{2} \mathrm{O}_{7}(\mathrm{OH})_{2} \cdot 2 \mathrm{H}_{2} \mathrm{O}$ Nanostructures. J. Phys. Chem. C 2009, 113, 8624-8629.
(35) Zhang, S.; Hou, M.; Lu, M.; et al. Synthesis and Electrochemical Performance of Cable-Like Copper Vanadates/Polypyrrole Nanobelts as Anode Materials for Lithium-Ion Batteries. Chem. Phys. Lett. 2016, 658, 203-206.

(36) Dai, J.; Lai, M.; LaFollette, R. M.; Reisner, D. Thin Film Copper Vanadium Oxide Electrodes for Thermal Batteries. ECS Trans. 2010, 33, 3-9.

(37) Bhowal, S.; Sannigrahi, J.; Majumdar, S.; Dasgupta, I. A Comparative Study of Electronic, Structural, and Magnetic Properties of $\alpha$-, $\beta$-, and $\gamma-\mathrm{Cu}_{2} \mathrm{~V}_{2} \mathrm{O}_{7}$. Phys. Rev. B: Condens. Matter Mater. Phys. 2017, 95, 075110.

(38) Prokofiev, A. V.; Kremer, R. K.; Assmus, W. Crystal Growth and Magnetic Properties of $\alpha-\mathrm{CuV}_{2} \mathrm{O}_{6}$. J. Cryst. Growth 2001, 231, 498-505.

(39) Yashima, M.; Susuki, R. O. Electronic Structure and Magenetic Propertiies of Monoclinic $\beta-\mathrm{Cu}_{2} \mathrm{~V}_{2} \mathrm{O}_{7} \mathrm{~A}$ GCA + U Study. Phys. Rev. $B$ 2009, 79, 125201-1-125201-6.

(40) Ghiyasiyan-Arani, M.; Masjedi-Arani, M.; Ghanbari, D.; Bagheri, S.; Salavati-Niasari, M. Novel Chemical Synthesis and Characterization of Copper Pyrovanadate Nanoparticles and its Influence on the Flame Retardancy of Polymeric Nanocomposites. Sci. Rep. 2016, 6, 25231.

(41) Machida, M.; Kawada, T.; Hebishima, S.; Hinokuma, S.; Takeshima, S. Macroporous Supported $\mathrm{Cu}-\mathrm{V}$ Oxide as a Promising Substitute as the Pt catalyst for Sulfuric Acid Decomposition in Solar Thermochemical Hydrogen Production. Chem. Mater. 2012, 24, 557561.

(42) Kawada, T.; Tajiri, T.; Yamashita, H.; Machida, M. Molten Copper Hexaoxodivanadate: An Efficient Catalyst of $\mathrm{SO}_{3}$ Decomposition in Solar Thermochemical Water Splitting Cycles. Catal. Sci. Technol. 2014, 4, 780-785.

(43) Kawada, T.; Hinokuma, S.; Machida, M. Structure and $\mathrm{SO}_{3}$ Decomposition Activity of $\mathrm{nCuO}-\mathrm{V}_{2} \mathrm{O}_{5} / \mathrm{SiO}_{2}(\mathrm{n}=0,1,2,3$ and 5) Catalysts for Solar Thermochemical Water Splitting Cycles. Catal. Today 2015, 242, 268-273.

(44) Rao, N. S.; Palanna, O. G. Phase Transitions in Copper (II) Orthovanadate. Bull. Mater. Sci. 1993, 16, 261-266.

(45) Krivovichev, S. V.; Filatov, S. K.; Cherepansky, P. N.; Armbruster, T.; Pankratova, O. Y. Crystal Structure of $\gamma-\mathrm{Cu}_{2} \mathrm{~V}_{2} \mathrm{O}_{7}$ and its Comparison to Blossite $\left(\alpha-\mathrm{Cu}_{2} \mathrm{~V}_{2} \mathrm{O}_{7}\right)$ and Ziesite $(\beta$ $\left.\mathrm{Cu}_{2} \mathrm{~V}_{2} \mathrm{O}_{7}\right)$. Can. Mineral. 2005, 43, 671-677.

(46) Slobodin, B. V.; Samigullina, R. F. Thermoanalytical Study of the Polymorphism and Melting Behavior of $\mathrm{Cu}_{2} \mathrm{~V}_{2} \mathrm{O}_{7}$. Inorg. Mater. 2010, 46, 196-200.

(47) Jerzierski, A.; Kaczkowski, J. Electronic Structure and Thermodynamic Properties of $\mathrm{Cu}_{3} \mathrm{~V}_{2} \mathrm{O}_{8}$ Compound. Phase Transitions 2015, 88, 970-978.

(48) Denisova, L. T.; Belousova, N. V.; Denisov, V. M.; Galiakhmetova, N. A. High-Temperature Heat Capacity of Oxides in the CuO- $\mathrm{V}_{2} \mathrm{O}_{5}$ System. Phys. Solid State 2017, 59, 1270-1274.

(49) Degen, T.; Sadki, M.; Bron, E.; König, U.; Nenert, G. The HighScore Suite. Powder Diffr. 2014, 29, S13-S18.

(50) Roy, D.; Samu, G. F.; Hossain, M. K.; Janáky, C.; Rajeshwar, K. On the Measured Optical Bandgap Values of Inorganic Oxide Semiconductors for Solar Fuels Generation. Catal. Today 2018, 300, $136-144$

(51) Hossain, M. K.; Samu, G. F.; Gandha, K.; Santhanagopalan, S.; Liu, J. P.; Janáky, C.; Rajeshwar, K. Solution Combustion Synthesis, Characterization, and Photocatalytic Activity of $\mathrm{CuBi}_{2} \mathrm{O}_{4}$ and its Nanocomposites with $\mathrm{CuO}$ and $\alpha-\mathrm{Bi}_{2} \mathrm{O}_{3}$. J. Phys. Chem. C 2017, 121, $8252-8261$

(52) Hohenberg, P.; Kohn, W. Inhomogeneous Electron Gas. Phys. Rev. 1964, 136, B864.

(53) Kohn, W.; Sham, L. J. Self-Consistent Equations Including Exchange and Correlation Effects. Phys. Rev. 1965, 140, A1133A1138.

(54) Kresse, G.; Furthmüller, J. Efficiency of Ab Initio Total Energy Calculations for Metals and Semiconductors Using a Plane-Wave Basis Set. Comput. Mater. Sci. 1996, 6, 15-50. 
(55) Kresse, G.; Furthmüller, J. Efficient Iterative Schemes for Ab Initio Total-Energy Calculations Using a Plane-Wave Basis Set. Phys. Rev. B: Condens. Matter Mater. Phys. 1996, 54, 11169-11186.

(56) Perdew, J. P.; Burke, K.; Ernzerhof, M. Generalized Gradient Approximation Made Simple. Phys. Rev. Lett. 1996, 77, 3865-3868.

(57) Blöchl, P. E. Projector Augmented-Wave Method. Phys. Rev. B: Condens. Matter Mater. Phys. 1994, 50, 17953-17979.

(58) Momma, K.; Izumi, F. VESTA: A Three-Dimensional Visualization System for Electronic and Structural Analysis. J. Appl. Crystallogr. 2008, 41, 653-658.

(59) Nagabhushana, G. P.; Nagaraju, G.; Chandrappa, G. T. Synthesis of Bismuth Vanadate: its Application in $\mathrm{H}_{2}$ evolution and Sunlight-Driven Photodegradation. J. Mater. Chem. A 2013, 1, 388394.

(60) Kakihana, M. Sol-Gel Preparation of High Temperature Superconducting Oxides. J. Sol-Gel Sci. Technol. 1996, 6, 7-55.

(61) Thomas, A.; Janáky, C.; Samu, G. F.; Huda, M. N.; Sarker, P.; Liu, J. P.; Van Nguyen, V.; Wang, E. H.; Schug, K. A.; Rajeshwar, K. Time- and Energy- Efficient Solution Combustion Synthesis of Binary Metal Tungstate Nanoparticles with Enhanced Photocatalytic Activity. ChemSusChem 2015, 8, 1652-1663.

(62) Kormányos, A.; Thomas, A.; Huda, M. N.; Sarker, P.; Liu, J. P.; Poudyal, N.; Janáky, C.; Rajeshwar, K. Solution Combustion Synthesis, Characterization, and Photoelectrochemistry of $\mathrm{CuNb}_{2} \mathrm{O}_{6}$ and $\mathrm{ZnNb}_{2} \mathrm{O}_{6}$ Nanoparticles. J. Phys. Chem. C 2016, 120, 1602416034.

(63) For example: Rajeshwar, K. Fundamentals of Semiconductor Electrochemistry and Photoelectrochemistry. In Encyclopedia of Electrochemistry; Licht, S., Ed.; Wiley-VCH: Weinheim, 2001; Chapter 1 , pp 3-53.

(64) Ma, X.; Cui, X.; Zhao, Z.; Melo, M. A.; Roberts, E. J.; Osterloh, F. E. Use of Surface Photovoltage Spectroscopy to Probe Energy Levels and Charge Carrier Dynamics in Transition Metal (Ni, Cu, Fe, $\mathrm{Mn}, \mathrm{Rh}$ ) Doped $\mathrm{SrTiO}_{3}$ Photocatalysts for $\mathrm{H}_{2}$ evolution from Water. J. Mater. Chem. A 2018, 6, 5774-5781.

(65) Wu, Z.; Cheung, G.; Wang, J.; Zhao, Z.; Osterloh, F. E. Wavelength Dependent Photochemical Charge Transfer at the $\mathrm{Cu}_{2} \mathrm{O}-\mathrm{BiVO}_{4}$ Particle Interface - Evidence for Tandem Excitation. Chem. Commun. 2018, 54, 9023-9026.

(66) Kwolek, P.; Szaciłowski, K. Photoelectrochemistry of n-Type Bismuth Oxyiodide. Electrochim. Acta 2013, 104, 448-453.

(67) Kronik, L.; Shapira, Y. Surface Photovoltage Spectroscopy of Semiconductor Structures: At the Crossroads of Physics, Chemistry and Electrical Engineering. Surf. Interface Anal. 2001, 31, 954-965.

(68) Zhou, L.; Yan, Q.; Yu, J.; Jones, R. J.; Becerra-Stasiewicz, N.; Suram, S. K.; Shinde, A.; Guevarra, D.; Neaton, J. B.; Persson, K. A.; Gregoire, J. M. Stability and Self-Passivation of Copper Vanadate Photoanodes under Chemical, Electrochemical, and Photoelectrochemical Operation. Phys. Chem. Chem. Phys. 2016, 18, 9349-9352.

(69) Gupta, S.; Yadava, Y. P.; Singh, R. A. Electrical Conduction in Copper Vanadate. Z. Phys. B: Condens. Matter 1987, 67, 179-183. 